\title{
Impact of Mediterranean diet on metabolic syndrome, cancer and longevity
}

\author{
Nicola Di Daniele ${ }^{1}$, Annalisa Noce ${ }^{1}$, Maria Francesca Vidiri², Eleonora Moriconi ${ }^{2}$, \\ Giulia Marrone ${ }^{1}$, Margherita Annicchiarico-Petruzzelli³ ${ }^{3}$ Gabriele D'Urso ${ }^{1}$, Manfredi \\ Tesauro ${ }^{1}$, Valentina Rovella ${ }^{1}$, Antonino De Lorenzo ${ }^{2}$ \\ ${ }^{1}$ Department of Systems Medicine, Hypertension and Nephrology Unit, University of Rome "Tor Vergata", Italy \\ 2Department of Biomedicine and Prevention, Division of Clinical Nutrition and Nutrigenomic, University of Rome "Tor Vergata", \\ Italy \\ ${ }^{3}$ Biochemistry Laboratory, IDI-IRCCS, Department of Experimental Medicine and Surgery, University of Rome "Tor Vergata", \\ Italy \\ Correspondence to: Annalisa Noce, email: annalisa.noce@libero.it \\ Nicola Di Daniele, email: didaniele@med.uniroma2.it
}

Keywords: Mediterranean diet, public health, obesity, cancer, antioxidant

Received: July 20, 2016

Accepted: November 07, 2016

Published: November 24, 2016

\section{ABSTRACT}

Obesity symbolizes a major public health problem. Overweight and obesity are associated to the occurrence of the metabolic syndrome and to adipose tissue dysfunction. The adipose tissue is metabolically active and an endocrine organ, whose dysregulation causes a low-grade inflammatory state and ectopic fat depositions. The Mediterranean Diet represents a possible therapy for metabolic syndrome, preventing adiposopathy or "sick fat" formation.

The Mediterranean Diet exerts protective effects in elderly subjects with and without baseline of chronic diseases. Recent studies have demonstrated a relationship between cancer and obesity. In the US, diet represents amount 30-35\% of death causes related to cancer. Currently, the cancer is the second cause of death after cardiovascular diseases worldwide. Furthermore, populations living in the Mediterranean area have a decreased incidence of cancer compared with populations living in Northern Europe or the US, likely due to healthier dietary habits. The bioactive food components have a potential preventive action on cancer. The aims of this review are to evaluate the impact of Mediterranean Diet on onset, progression and regression of metabolic syndrome, cancer and on longevity.

\section{INTRODUCTION}

Obesity and metabolic syndrome (MetS) showed a significant increase in the last decades, becoming a public health problem due to high hospitalization rates, treatment costs and impaired quality of life.

Both obesity that MetS are characterized by insulin resistance that expose the patients to an increased risk of cardiovascular disease and cancer, despite the healthy nutritional habits [1]. In fact only $5-10 \%$ of cancer cases are linked to genetic causes while $90-95 \%$ can be attributed to environment and lifestyle [2].

The Mediterranean Diet (MD) is characterized by an adequately balanced combination of fruit and vegetables, fish, cereals, and polyunsaturated fats, with a reduced consumption of meat and dairy products and moderate intake of alcohol, primarily red wine. The value of this diet lies in its ability to preserve the state of health and improve longevity, as United Nations Educational, Scientific and Cultural Organization (UNESCO) declared in 2010 [3].

Scientific evidence has showed that the adoption of the Mediterranean diet is a protective factor against the onset of various types of cancer, cardiovascular disease, aging and obesity. As shown by the Epic (European Prospective Investigation into Cancer and Nutrition) study, the MD is the most effective in the prevention of several chronic diseases, including cancer.

The nutrients that are found in abundance in the Mediterranean diet have anti-cancer, anti-inflammatory, anti-obesity properties and contribute together to the maintenance of health status. The anti-tumor effects of the Mediterranean diet are mostly due to the combination 
of antioxidant elements, fiber and polyunsaturated fats. This dietary pattern is therefore essential as a preventive measure against the onset of cancer and other chronic diseases but also to reduce health care costs.

\section{MEDITERRANEAN DIET, METABOLIC SYNDROME (METS) AND OBESITY}

\section{Definition and classification of Mets}

Overweight and obesity are highly prevalent worldwide. One billion people in the world are overweight and 300 million are considered obese. Several studies estimate that in 2030, approximately 2 billion people will be overweight and 1,12 billion obese [4]. In the United States, abdominal obesity has tripled during the past 40 years [5]. More than $25 \%$ of the US population can be classified as having the MetS [6]. MetS prevalence has increased from $34.3 \%$ to $38.5 \%$ during the past 15 years $[7,8]$. Given the prevalence of the phenomenon, obesity is considered an important public health problem, with a strong impact on health status, economy and quality of life. The accumulated adipose tissue, particularly central adiposity, generates a chronic low-grade inflammatory state that is the basis of metabolic disturbances, such as insulin resistance, dyslipidemia and hyperuricemia. Insulin resistance is the "core" of the MetS and abdominal obesity plays a central role in this syndrome.

MetS is characterized by dyslipidemia and arterial hypertension, which are associated with increased risk of type 2 diabetes mellitus (T2DM) and cardiovascular diseases (CVD) [9]. The relationship between obesity and T2DM is so strong that the new term "diabesity" has been introduced. It is a global pandemic favoured by an obesogenic environment that promotes consumption of energy-dense foods and discourages energy expenditure, with the result of weight gain. In recent years there has been an increase in the incidence of obesity in young people, with the result that T2DM and MetS are not exclusive to adulthood but are increasingly observed in childhood [10].

In addition, several types of cancers, including uterine, breast, colon, prostate and kidney are obesity driven $[8,9]$. Studies indicate that, over the past decade, $25 \%$ of all cancers could be prevented by reducing the rate of obesity [13-15].

Several definitions for MetS have been proposed. In 1988, Reaven first spoke of "the syndrome X," which is currently defined "Metabolic Syndrome". Reaven noticed a close link between risk factors of CVD (glucose intolerance, hyperinsulinemia, high serum triglycerides, low serum highdensity lipoprotein cholesterol) and arterial hypertension. Moreover, a prothrombotic and chronic inflammatory state, often is associated with MetS and added subsequently to its definition [16, 17]. As late as the 1990s, World Health Organization (WHO) defined MetS as insulin resistance or diabetes or impaired glucose tolerance or impaired fasting glucose, plus two of these conditions: body mass index $\geq 30 \mathrm{~kg} / \mathrm{m}^{2}$ or waist/hip ratio $>0,9$ (man) / >0,85 (woman); blood pressure $\geq 140 / 90 \mathrm{mmHg}$ or antihypertensive treatment; triglycerides $\geq 1,7 \mathrm{mmol} / 1(150 \mathrm{mg} / \mathrm{dl})$ or lipidlowering treatment; $\mathrm{HDL}<0,9 \mathrm{mmol} / 1(35 \mathrm{mg} / \mathrm{dl})(\mathrm{man})<1,0$ (39 mg/dl) (woman); albuminuria [18].

Later the National Cholesterol Education Program's Adult Treatment Panel III report (NCEP ATP III) and International Diabetes Federation (IDF) proposed a new set of criteria with ethnic/racial specific cut-offs to define MetS. This study group gave less attention to the criteria albuminuria and focused on abdominal obesity expressed as waist circumference. In particular, IDF considers waist circumference as essential criteria of MetS. The main difference between NCEP-ATP III and IDF MetS definition consists in the cut-offs chosen. The definitions of the MetS are summarized in Table 1. The concept of MetS has been disputed [19, 20], it is still recognized as a major risk factor cluster for $\mathrm{CV}$ disease, even in older subjects in whom MetS confers a 38\% higher risk of myocardial infarction and stroke [21-23].

Despite the increased urinary albumin excretion (UAE) is not currently reported in diagnostic criteria of the MetS, recent studies had showed that albuminuria is considered an important indicator of cardiovascular risk. Actually, albuminuria and estimated glomerular filtration rate (eGFR) are considered not only biomarkers of progression and diagnosis of chronic Kidney disease (CKD) but also are significantly correlated with MetS and its components [24, 25]. In particular, a recent study proposed to reintroduce, in the diagnostic criteria of MetS, the albuminuria and elevated high-sensitive C- Reactive Protein (hs-CRP) [26]. In fact, albuminuria and hs-CRP are widely recognized as biomarkers of systemic endothelial dysfunction and low-grade chronic inflammation, respectively. According to guidelines, elevated UAE was defined as UAE $\geq 30 \mathrm{mg} / 24 \mathrm{~h}$ and high hs-CRP as a hs-CRP $\geq 3 \mathrm{mg} / 1[22,23]$. Elevated UAE is associated to higher risk of new-onset T2DM, CVD and CKD, whereas hs-CRP is only correlated to new onset CVD and CKD, but not with the onset of T2DM [27]. In fact albuminuria is not only a complication of T2DM but also can precede it [27-30]. In line with these studies, it has been suggested that since the birth, UAE levels are genetically determined and influenced by factors present in the intra-uterine environmental. These values represent both the state vascular and the individual susceptibility to organ damage [26-31].

\section{Phenotypes of obesity}

Obesity can be categorised according to four phenotypes: 1) Normal weight obese (NOW) [32]; 2) Metabolically obese normal weight (MONW) [33, 34]; 3) Metabolically healthy obese (MHO); and 4) Metabolically unhealthy obese (MUO) or "at risk obese" with MetS 
Table 1: Main definitions of Metabolic Syndrome

\begin{tabular}{|c|c|c|}
\hline WH0 (1998) [15] & NCEP/ATP III (2001-2005) [257] & IDF (2005) [258] \\
\hline $\begin{array}{l}\text { Insulin resistance or diabetes or } \\
\text { impaired glucose tolerance or } \\
\text { impaired fasting glucose, plus two of } \\
\text { these conditions }\end{array}$ & At least 3 of the following: & $\begin{array}{c}\text { Abdominal obesity defined as waist } \\
\text { circumference } \geq 94 \mathrm{~cm} \text { in men and } \geq 80 \\
\mathrm{~cm} \text { in women } \\
\text { Plus at least two of the following } \\
\text { criteria: }\end{array}$ \\
\hline $\begin{array}{l}\checkmark \text { Body mass index } \geq 30 \mathrm{~kg} / \mathrm{m}^{2} \text { or waist } \\
\text { ratio }>0,9 \mathrm{man} / 0,85 \text { woman; }\end{array}$ & $\begin{array}{l}\checkmark \text { Waist circumferences } \geq 102 \mathrm{~cm} \text { man } \\
\text { and } 88 \text { woman; }\end{array}$ & $\begin{array}{l}\checkmark \text { Increased fasting tryglicerides }>150 \\
\mathrm{mg} / \mathrm{dl}(\geq 1,7 \mathrm{mmol} / \mathrm{l}) \text { or lipid lowering } \\
\text { treatment; }\end{array}$ \\
\hline $\begin{array}{l}\checkmark \text { Blood pressure } \geq 140 / 90 \mathrm{mmHg} \text { or } \\
\text { antihypertensive treatment; }\end{array}$ & $\begin{array}{l}\checkmark \text { Blood pressure } \geq 130 / 85 \mathrm{mmHg} \text {, or } \\
\text { antihypertensive treatment; }\end{array}$ & $\begin{array}{l}\checkmark \text { HDL }<0,9 \mathrm{mmol} / 1(40 \mathrm{mg} / \mathrm{dl}) \text { man } \\
<1,1(50 \mathrm{mg} / \mathrm{dl}) \text { women or lipid } \\
\text { lowering treatment; }\end{array}$ \\
\hline $\begin{array}{l}\checkmark \text { Triglycerides } \geq 1,7 \mathrm{mmol} /(150 \mathrm{mg} / \\
\mathrm{dl}) \text { or lipid lowering treatment; }\end{array}$ & $\begin{array}{l}\checkmark \text { Triglycerides } \geq 1,7 \mathrm{mmol} /(150 \mathrm{mg} / \\
\mathrm{dl}) \text { or lipid lowering treatment; }\end{array}$ & $\begin{array}{l}\checkmark \text { Increased blood pressure } \geq 130 / 85 \\
\text { mmHg, or antihypertensive treatment; }\end{array}$ \\
\hline $\begin{array}{l}\checkmark \text { HDL }<0,9 \mathrm{mmol} / 1(35 \mathrm{mg} / \mathrm{dl}) \mathrm{man} \\
\quad<1,0(39 \mathrm{mg} / \mathrm{dl}) \text { woman; }\end{array}$ & $\begin{array}{l}\checkmark \text { HDL }<1 \mathrm{mmol} / 1(39 \mathrm{mg} / \mathrm{dl}) \mathrm{man} \\
\quad<1,3(50 \mathrm{mg} / \mathrm{dl}) \text { woman; }\end{array}$ & $\begin{array}{l}\checkmark \text { High level of fasting glucose }>100 \\
\text { mg/dl }(5,6 \mathrm{mmol} / \mathrm{l}), \text { or T2DM; }\end{array}$ \\
\hline $\begin{array}{l}\checkmark \text { Glucose } 5,6 \mathrm{mmol} / \mathrm{dl}(101 \mathrm{mg} / \mathrm{dl}) \text { or } \\
\text { hypoglycemic treatment; }\end{array}$ & $\begin{array}{l}\checkmark \text { Glucose } 5,6 \mathrm{mmol} / \mathrm{dl}(101 \mathrm{mg} / \mathrm{dl}) \text { or } \\
\text { hypoglycemic treatment; }\end{array}$ & \\
\hline$\checkmark$ Microalbuminuria; & & \\
\hline
\end{tabular}

\section{Legend Table 1:}

\section{HDL: High Density Lipoprotein}

IDF: International Diabetes Federation

NCEP ATP III: National Cholesterol Education Program's Adult Treatment Panel III report

T2DM: type 2 diabetes mellitus

WHO: World Healt Organization

Main definitions drawn up by the WHO, NCEP/ ATP III and IDF of MetS recognized by the scientific world.

[35]. Furthermore, the sarcopenic obesity was described and related to all these obesity phenotypes [36]. NWO syndrome was defined firstly by De Lorenzo et al, in order to indicate subjects with normal Body Mass Index (BMI) $\left(18.5-24.9 \mathrm{~kg} / \mathrm{m}^{2}\right)$ and high body fat percentage $(\mathrm{PBF} \%)(\mathrm{man} \geq 23.5 \%$, woman $\geq 29.2 \%)$. They develop early oxidative stress and chronic inflammatory status and they have higher risk of cardio-metabolic diseases and sarcopenic obesity [37]. The inflammation is explained by the presence of single nucleotides polymorphisms (SNPs) in specific genes, such as $-174 \mathrm{G} / \mathrm{C}$ promoter polymorphism of the IL-6 gene that correlates to insulin resistance $[38,39]$, polymorphism in IL-15 receptor alpha, in methylenetetrahydrofolate reductase (MTHFR) genes [40] and in G/A -308 Tumor Necrosis Factor-alpha (TNF- $\alpha$ ). The latter is associated to sarcopenic obesity [41]. MONW subjects have a normal weight but metabolic alterations typical of MetS (such as high blood pressure, low insulin sensitivity and dyslipidemia) [42, 43]. The higher amount of visceral fat in this phenotype leads to higher blood levels of inflammation cytokines (TNF- $\alpha$ and Interleukin-6 (IL6) [44]. $M H O$, although have an excess of body fat, are metabolically healthy individuals. In fact, $20-30 \%$ of obese adults do not show the metabolic complication associated with obesity. MHO individuals have high insulin-sensitivity, normal blood pressure, no signs of chronic inflammation and normal lipid profile. Therefore, the inflammation is correlated to increasing of adipose tissue but is not always linked to obesity $[45,46]$. MUO, are also called "at risk" obese subjects. They are obese for both anthropometric parameters $\left(\mathrm{BMI} \geq 30 \mathrm{~kg} / \mathrm{m}^{2}\right)$ and fat mass percentage (PBF $>30 \%$ ) and develop metabolic abnormalities such as MetS, T2DM and atherosclerotic CVD [47, 48]. This phenotype is linked to higher visceral adiposity than subcutaneous adiposity and consequently to a greater fatty acids release into the portal circulation and major deposition in liver [49].

The concept of Sarcopenic Obesity was introduced firstly by Roubenoff and co-workers [36], who suggested that the inflammation of visceral fat promotes muscle catabolism leading to a loss of muscle mass and muscle 
weakness [50]. Schrager et al demonstrated that sarcopenic obesity was directly related to higher levels of IL-6, CRP, IL-1 receptor antagonist and IL-7; consequently these cytokines were involved in both the development and progression of sarcopenic obesity [51]. The identification of obesity phenotypes can allow early detection the subjects at risk to develop the MetS in order to carry out timely personalized diet and drug treatment intervention.

\section{Adiposopathy and inflammation}

The complexity of the "phenotype" MetS is related to two pathogenetic factors: adipose tissue (AT) and inflammation. AT is now considered not only a fat storage, but an active endocrine organ. It produces inflammatory cytokines, such as leptin, adiponectin, TNF- $\alpha$, IL-1, IL-6 and pro-coagulant substances (PAI-1) that are associated with a chronic low-grade inflammation. Also the AT can produce vasoactive factors and molecules promoting insulin resistance (IR): free fatty acids (FFA), resistin and retinol binding protein 4 [52]. The AT consists of two compartments: brown adipose tissue (BAT), which is associated with thermogenesis, and white adipose tissue (WAT), lipid storage used during periods of nutrient deprivation. In literature, BAT was considered active only in infants and its thermogenic role finished after early months of life. However, recent findings have established that the BAT activity increases from childhood to adolescence with a peak at 13 years [53] and that BAT functional deposits are still present in adulthood [54]. Several studies have shown that exposure to cold in healthy volunteers rapidly increases the production of BAT, accumulating mainly in supraclavicular, laterocervical, paraspinal and mediastinal sites [55]. The authors have found also an endocrine function of BAT even if further analysis are needed to explain its ability to turn into WAT and its correlation with obesity [56]. The main role of WAT is energy and fat storage, however, it is also considered an endocrine organ. The WAT endocrine and deposit activity is largely determined in the early stages of life and is essential for its development and its pro-inflammatory property [57]. From the young age, the adipokines released by WAT are associated with the major cardio-metabolic complications of obesity (such as IR, elevated arterial blood pressure, dyslipidemia, T2DM and atherosclerosis).

During life, there are "permissive windows" in which the cells, tissues and organs are more sensitive to external signals. These periods particularly sensitive for the proliferation and differentiation of adiposities are the first year of life, years three to five (known as adiposity rebound period) and years nine to thirteen (puberty) [58, 59]. In turn WAT is divided in: visceral adipose tissue (VAT) and subcutaneous adipose tissue (SAT). The first is formed by mesenteric and omental fat and other deposits are localized in epicardial region and the latter is localized over the entire body surface, particularly in woman in breast and gluteo-femoral regions while in man in abdomen site. Although the VAT represents only $10-20 \%$ of the total fat, it is more associated with cardiometabolic diseases [60]. Its pathogenic role is related to its location: VAT is more vascularized compared to SAT, releases a larger share of pro-inflammatory cytokines (as IL-6, IL-8, and TNF- $\alpha$ ) and fatty acids in the blood stream. In fact, the "portal hypothesis" asserts that VAT is linked to an increased cardiovascular risk because fatty acids are poured in the portal blood and cause IR and vascular damage. Consequently, in according to Framingham Hearth Study, VAT is considered as an independent risk factor of CVD [61].

During positive caloric balance, adipocytes initially become hypertrophic, trigging paracrine adipogenic signaling in order to recruit other fat cells and to maintain AT physiologic functions during increased energy storage [62-64]. When the positive energy balance persists, adipogenesis is impaired causing adipocyte dysfunction [65]. The anatomic/functional alterations of AT, promoted by positive caloric balance, in genetically and environmentally susceptible individuals, are responsible of "adiposopathy" or "sick fat". The endocrine and immune responses caused by the "adiposopathy" increase and/ or exacerbate metabolic disorders and CVD risk factors (such as T2DM, high blood pressure and dyslipidemia) [66]. Furthermore, an increased fat storage induces adipocyte hypertrophy and intracellular hypoxia, causing the release of FFA in the blood. The "spill over" of lipids from dysfunctional adipocyte [67] lead to ectopic fat deposition in non adipose tissue/organ (such as liver, muscle, pancreas, kidney and blood vessels) causing "lipotoxicity". In the muscle, lipotoxicity causes IR and in the pancreas reduces insulin secretion [66]. This process is the base of "meta-inflammation", a chronic low-grade inflammatory state caused by obesity [68]. The lipid storage capacity decrease inhibits preadipocytes differentiation and increases lipolysis. In particular, TNF- $\alpha$ stimulates lipolysis in adipocyte by impairing the function of two enzymes, the hormone-sensitive lipase (HSL) and the fatty triglyceride lipase (ATGL). In this scenario, the macrophage infiltration in AT grows proportionally to BMI, fat mass and adipocyte hypertrophy and is a reversible process in obese patients who lose weight. The chemo-attractant factors such as monocyte-chemotactic protein-1 (MCP-1), chemerin, progranulin and colony stimulating factor-1 (CSF-1) allow the recruitment of macrophages from the bloodstream into AT [69] and the shift from a profile mainly anti-inflammatory (M2 macrophages) to a pro-inflammatory profile (M1 macrophages) [68]. M1 macrophages induce aerobic glycolysis and they are linked to inflammation and IR. M2 macrophages active oxidative metabolism and release anti-inflammatory cytokines [70]. 
The greater availability of circulating FFA produces storages outside the AT, causing cell dysfunction and cell death. This process (lipotoxicity) is involved in beta cell loss during the progression of T2DM (contributing to insulinopenia) and in the pathogenesis of complications related to T2DM injuring cardiomyocytes, hepatocytes, kidney parenchimal cells and endothelial cells [71, 72]. Recently, several deposits of adipose ectopic tissue are discovered in transgenic animal models [73]. One of the most involved organs in ectopic fat deposition is the liver, that is fundamental for oxidation and metabolism of FFA. During a positive caloric balance adipocyte hypertrophy and accumulation of VAT may contribute to enhance the flow of FFA to the liver, causing liver steatosis. Patients "inflexible" to hepatic metabolism of fatty acids are more prone to the accumulation of lipids in the liver and, consequently, the development of IR and dyslipidemia $[64,74]$. Ectopic fats depots are also localized in the renal sinus (RS), where they may compress the renal vein and artery, increase kidney interstitial pressure and decrease sodium excretion. This condition is responsible for both arterial hypertension and CKD [75-77]. Several studies $[78,79]$ have recently demonstrated an ectopic adipose depot in epicardial region. The Epicardial Adipose Tissue (EAT) is metabolically active and located between the heart and pericardium. Anatomically it presents a prevalent localization around the right ventricle [80]. EAT produces several bioactive adipokines, as well as pro-inflammatory cytokines and pro-atherogenic substances such as TNF- $\alpha$, IL-6, resistin, visfatin, omentin, leptin, PAI-1 and angiotensinogen. EAT is also associated with T2DM and obesity [81]. Under physiological conditions, the EAT plays a cardio-protective role through the local secretion of adipokines with anti-inflammatory and anti-atherogenic proprieties, as adiponectin and adrenomedullin. However in pathological conditions, the increase in thickness of the epicardial fat reflects the expansion of adipose tissue and visceral infarction, contributing to the development of MetS and coronary artery disease. Given its significant clinical implication, the evaluation of the EAT has been proposed as therapeutic target during the diet therapy or during pharmacological treatments directly or indirectly in order to weight loss [82]. During the redistribution of fat depots, adiposity is located undereath the deep fascia of the thigh and inside the muscles. This ectopic fat depot, called intermuscular adipose tissue (IMAT), is linked to insulin sensitivity in obese individual [83]. IMAT is also a significant predictor of both muscle and mobility function in older adults [84]. In this scenario, MetS cannot be related only to the increase in BMI but also to quantitative and qualitative enhancement of the AT and its localization.

\section{Nutrigenetics and nutrigenomic}

Nutrition is probably the principal environmental factor that conditions the expression of genes involved in MetS. Nutrigenomics is defined as a prospective analysis of the differences between nutrients in relation to their impact on gene expression and finally on human health. Nutrigenomics allows us to study the interactions between nutrients and genes in order to establish a diet program according to the individual genetic profile and represents a tool to understand how the components of a particular diet (bioactive compounds) can alter gene expression, through their down and-or up regulation. The Nutrigenomics is a useful instrument in the prevention of Non-Transmissible Chronic Diseases (NTCDs) [85]. Nutrigenetics is a retrospective analysis of people genetic variations and their clinical response to specific nutrients. The term nutrigenetics was introduced by Brennan in 1975 [86]. Nutrigenetics approach was widely studied: the inter-individual differences in response to dietary factors underline the role of genes. Nutrient intake is manipulated or optimized according to an individuals' genetic profile in order to reduce the risk to onset disease. The relationship between nutrigenetics and obesity, MetS and T2DM is largely based on data relating to dietary fat [87-89]. Sedentary lifestyle behaviour and a greater availability by high-calorie foods, in particular high fat food, are associated to obesity and CVD. The "thrifty genes" play a central role in the development of obesity and metabolic disorders. In the past, these genes promoted fat deposition as energy storage during times of food deprivation. Actually, in a modern environment of physical inactivity and excessive caloric consumption, the thrifty genes are associated to obesity and T2DM [90, 91]. Several studies support the interaction between genes and environment. The different nutritional responses are caused by SNPs mutations that occur in a single code base of a gene. They are very frequent: $1 \mathrm{SNP}$ for $1,91 \mathrm{~Kb}$ DNA sequence and $5 \%$ of all cases of obesity and diabetes has been associated with monogenic disorders. The mutated genes, related to obesity, include leptin (LEP), leptin receptor (LEPR), pro-opiomelanocortin (POMC) and melanocortin-4 receptor (MC4R) [92]. Genome-wide association studies (GWAS) have evaluated susceptibility genes of T2DM and obesity. In particular, Calpain 10 (CAPN10), that encodes cysteine protease calpain 10 , has been the first identified T2DM susceptibility gene [93]. Also, two Single Nucleotides polymorphism (SNPs) are associated with T2DM risk: transcription factor 7-like 2 (TCF7L2) and fat mass and obesity-associated (FTO) gene on chromosome 16. TCF7L2 polymorphisms is related to high risk of dyslipidemia and increased waist circumference. While the homozygous mutation of FTO gene (FTO rs9939609 mutation) is associated to $3 \mathrm{~kg}$ heavier and had 1,7 fold increased risk of obesity than the homozygous nonrisk allele carriers [94]. Actually, FTO rs9939609 SNP is considered one of the most important gene variants predisposing to obesity [95] and the LIPGENE-SU.VI MAX study showed that FTO rs9939609 is also associated with overweight and abdominally obesity [96]. 
Numerous genes are also linked to an increased susceptibility to dyslipidemia, particularly peroxisome proliferator-activated receptor $\gamma(\operatorname{PPAR} \gamma)$, a nuclear receptor that regulates adipocyte differentiation, lipid storage, fat-specific gene expression and insulin action. The most prevalent SNPs variants of PPAR $\gamma$ gene identified is the Pro12Ala, correlated to T2DM, obesity, and other clinical disorders [97, 98]. Patients with T2DM carrying the Pro12Ala polymorphism have higher risk of obesity than non-carriers although the same energy intake, perhaps secondary to a better insulin sensitivity [99]. LIPGENE-SU.VI.MAX study shows that not only mutation in glucose metabolism but also in fatty acid metabolism cause IR and dyslipidemia, as evidenced by mutations in longchain acyl CoA synthetase 1 (ACSL1) gene that is an important enzyme for mitochondrial beta-oxidation of long chain fatty acids. The polymorphisms (rs4862417, rs6552828, rs13120078, rs9997745 and rs12503643) in this locus genes increase MetS risk. Furthermore, a low fat dietary or a total dietary polynsatured fatty acids (PUFA) intake higher to $50^{\text {th }}$ percentile decrease the MetS risk in $(\mathrm{G}+)$ carriers [100]. The same study indicates that GG homozygotes of rs3790433 SNP at the LEPR gene have higher IR and increased MetS risk. The latter is exacerbated by a diet rich in n-6 PUFA and poor in n-3 PUFA, whereas a high n-3 or low n-6 PUFA background reduces the likelihood of developing MetS [101]. Both obesity and the MetS are characterized by a low-grade inflammatory state that causes or exacerbates their co-morbidities. A proper nutrigenomic approach is useful for reducing this inflammation. In fact, foods containing anti-inflammatory bioactives, such as caffeic acid (Yerba mate), tyrosol (olive oil), quercetin (fruits and vegetables), licopene (tomatoes an watermelon) and $\alpha$-tocoferol (green tea) are able to reduce the inflammation. Its reduction is led by lower expression of ciclo-oxigenase-2 (COX-2) and inducible nitric oxide synthase (iNOS) genes after the inhibition of Kappa B-nuclear factor's translocation from the cytoplasm to the nucleus $[102,103]$. Actually nutrigenomics, with the other "omics" sciences (such as Proteomics, Metabolomics and Transcriptomics), represents a pivotal tool in evaluating, treating and preventing different future diseases, especially in the area of NTCDs [85].

Nutrigenetic can be used to compose a personalized diet and in this scenario, an interesting study of Arkadianos et al. have shown that the inclusion of genetic information to personalize patient's diet improves the long term BMI reduction and blood glucose levels. In particular, the authors examined in 24 patients, the variants of 19 genes involved in the metabolism, such as methylenetetrahyidrofolate reductase (MTHFR), glutathione S-transferase (GST), superoxide-dismutase (SOD) 2 and 3 and vitamin D receptor (VDR) polymorphisms [104].
De Lorenzo et al., in other paper, have demonstrated that $\mathrm{T}(+)$ carriers in C677T MTHFR polymorphism have higher cardiovascular disease risk, osteoporosis and sarcopenia. In particular, the authors examined the impact of the C677T MTHFR gene polymorphism on body composition change induced by a balance hypocaloric Italian Mediterranean Diet. Before the nutritional intervention, $\mathrm{T}(+)$ carriers patients were fatter than $\mathrm{T}(-)$ carriers and after the nutritional intervention $\mathrm{T}(+)$ carriers had lower increase in total body lean/total body fat ratio compared to T (-) carriers [105]. The increased CV risk for $\mathrm{T}(+)$ carriers is due to hyperhomocysteinemia related in turn to lack of 5-methyltetrahydrofolate, necessary to methylate homocysteine (Hcy) into methionine.

Hyperhomocysteinemia is also associated to neural tube defects [106], Alzheimer's disease [107] and osteoporosis. The MTHFR polymorphism effects on bone mineral density (BMD) depend on folate status. The mechanism mediating this association, however, remains unclear, but may be partially caused by homocysteine effects on bone [108]. The nutrigenomic intervention by the supplementation of Folic acid and Vitamin B 12 is useful to reduce and, in some case, to normalize plasma Hcy concentrations. A meta-analysis of 25 randomized controlled trials, involving 2596 subjects, assessed that daily dose of $\geq 0.8 \mathrm{mg}$ folic acid is able to induce the maximal reduction in plasma Hcy levels and the dose between 0.2 and $0.4 \mathrm{mg}$ is associated with $60 \%$ and $90 \%$, respectively, of this maximal effect [109]. Moreover the alternating vitamin treatment with folic acid and vitamin B12 confirmed the importance of folate therapy and secondary contribution of vitamin B12 in lowering Hcy also in haemodialysis patients with MTHFR genotype [110] (Table 2).

\section{Impact of mediterranean diet on metabolic syndrome and obesity}

The Seven Country Study, an International Cooperative Study on coronary heart disease epidemiology, promoted by the American physiologist Ancel Keys and the Italian Flaminio Fidanza, investigated the benefits of the MD on human health, comparing European rural cohorts (the Mediterranean cohorts Crete, Corfù, Crevalcore, Montegiorgio and Dalmatia) and the non-Mediterranean cohorts (East and West Finland, Slavonia and Velika Krsna).

In order to assess the adhesion to the Healthy Reference National Mediterranean Diet (HRNMD), it was introduced the Mediterranean Adequacy Index (MAI). It is calculated by dividing the sum of total energy percentages of the food groups typical of HRNMD (bread, cereals, legumes, potatoes, vegetables, fresh fruit, nuts, fish, wine, vegetable oil), by the sum of the dietary energy percentage of food groups that are not characteristic of a HRNMD (milk, cheese, meat, eggs, animal fats and margarines, sweet beverages, cakes, pies, cookies and 
Table 2: Interaction genes and nutrients

\begin{tabular}{|c|c|c|c|c|c|c|}
\hline Biological Process & Gene & Polymorphism & Genotype & Biomarker & $\begin{array}{l}\text { Nutritional } \\
\text { Factor }\end{array}$ & $\begin{array}{c}\text { Dose genotype } \\
\text { dependent }\end{array}$ \\
\hline \multirow{12}{*}{ INFLAMMATION } & \multirow{3}{*}{ MTHFR } & \multirow{3}{*}{$677 \mathrm{C} / \mathrm{T}$} & $\mathrm{C} / \mathrm{C}$ & \multirow{3}{*}{ Homocysteine } & \multirow{3}{*}{ Folic Acid } & 200 ( $\mu \mathrm{g} /$ day $)$ \\
\hline & & & $\mathrm{C} / \mathrm{T}$ & & & 400 ( $\mu \mathrm{g} /$ day $)$ \\
\hline & & & $\mathrm{T} / \mathrm{T}$ & & & 800 ( $\mu \mathrm{g} /$ day) \\
\hline & \multirow{3}{*}{ MTHFR } & \multirow{3}{*}{$1298 \mathrm{~A} / \mathrm{C}$} & AA & \multirow{3}{*}{ Homocysteine } & \multirow{3}{*}{ Folic Acid } & 200 ( $\mu \mathrm{g} /$ day $)$ \\
\hline & & & $\mathrm{AC}$ & & & 400 ( $\mu \mathrm{g} /$ day $)$ \\
\hline & & & $\mathrm{CC}$ & & & 800 ( $\mu \mathrm{g} /$ day $)$ \\
\hline & \multirow{3}{*}{ IL-6 } & \multirow{3}{*}{$-174 \mathrm{G} / \mathrm{C}$} & $\mathrm{G} / \mathrm{G}$ & & \multirow{3}{*}{ Ù 3} & 1,5 (g/day) \\
\hline & & & $\mathrm{G} / \mathrm{C}$ & & & $1,5-3$ (g/day) \\
\hline & & & $\mathrm{C} / \mathrm{C}$ & $\begin{array}{l}\text { C-Reactive } \\
\text { Protein }\end{array}$ & & $1,5-3$ (g/day) \\
\hline & \multirow{3}{*}{ TNF- $\alpha$} & \multirow{3}{*}{$-308 \mathrm{G} / \mathrm{A}$} & $\mathrm{G} / \mathrm{G}$ & Lipoxygenase & \multirow{3}{*}{ Ù 3} & 1,5 (g/day) \\
\hline & & & $\mathrm{G} / \mathrm{A}$ & & & $1,5-3$ (g/day) \\
\hline & & & $\mathrm{A} / \mathrm{A}$ & & & $1,5-3$ (g/day) \\
\hline \multirow{9}{*}{$\begin{array}{l}\text { STRESS } \\
\text { OXIDATIVE }\end{array}$} & \multirow{3}{*}{ SOD2 } & \multirow{3}{*}{$-28 \mathrm{C} / \mathrm{T}$} & $\mathrm{CC}$ & & \multirow{3}{*}{ Ù 3} & 1,5 (g/day) \\
\hline & & & $\mathrm{CT}$ & & & $1,5-3$ (g/day) \\
\hline & & & TT & & & $1,5-3$ (g/day) \\
\hline & \multirow{3}{*}{ CYP1A2 } & \multirow{3}{*}{$-163 \mathrm{~A} / \mathrm{C}$} & $\mathrm{AA}$ & LDL ossidate & \multirow{3}{*}{ Ù 3} & 1,5 (g/day) \\
\hline & & & $\mathrm{AC}$ & $\begin{array}{c}\mathrm{NO}_{2} / \mathrm{NO}_{3} \\
\mathrm{ANPC}\end{array}$ & & $1,5-3$ (g/day) \\
\hline & & & $\mathrm{CC}$ & ORAC & & $1,5-3$ (g/day) \\
\hline & \multirow{3}{*}{ GSTM1 } & \multirow{3}{*}{ ID } & II & & \multirow{3}{*}{ Ù 3} & 1,5 (g/day) \\
\hline & & & ID & & & $1,5-3$ (g/day) \\
\hline & & & DD & & & $1,5-3$ (g/day) \\
\hline \multirow{3}{*}{$\begin{array}{l}\text { LIPIDS } \\
\text { METABOLISM }\end{array}$} & \multirow{3}{*}{ APOA1 } & \multirow{3}{*}{$-75 \mathrm{G} / \mathrm{A}$} & GG & & \multirow{3}{*}{ PUFA } & $<4 \%$ \\
\hline & & & GA & LDL oxidized & & $4-8 \%$ \\
\hline & & & AA & & & $>8 \%$ \\
\hline
\end{tabular}

\section{Legend Table 2:}

APOA1: Apolipoprotein A1

CYP1A2:Cytochrome P450 1A2

GSTM1: Glutathione S-transferase Mu 1

IL-6: interleukin-6

MTHFR: methylenetetrahydrofolate reductase

SOD2: Superoxide dismutase 2

TNF- $\alpha$ : tumor necrosis factor alpha

Personalized diet therapy intervention and nutrients dose change according to genetic polymorphisms. 
sugar). The membership of food to one of two groups is based on the results of a dietary survey carried out in 1960 in a sub-sample of Nicotera man aged 45-54 years. Nicotera was chosen for low frequency of cardiovascular diseases, T2DM and arterial hypertension [111-113]. The MAI was inversely associated with the 25 -year death rates from cardiac heart disease (CHD). In particular, a 2.7point increase of MAI was associated with a CHD mortality decrease of $26 \%$ in 20 years of follow-ups and of $21 \%$ in 40 years of follow-ups in two Italian rural cohorts of the Seven Countries Study, Crevalcore and Montegiorgio. It was demonstrated that this association is independent from possible confounding factors, such as age, cigarette consumption, systolic blood pressure, serum cholesterol, physical activity and BMI [113]. A longitudinal study of Alberti-Fidanza et al. has evaluated how much near or far eating habits of population are from a reference MD. They were investigated men (aged 45-65 years) from rural areas of Italy in the Seven Countries Study for 26 years (Crevalcore and Montegiorgio), elderly men and women from Perugia for 11 years, men and women from Pollica (Salerno) for 32 years and families from Rofrano (Salerno) for 41 years. The median value of MAI among Nicotera's people was 7.2. The examination during four decades has showed that the diet over the years has abandoned the nutritional characteristics of the reference ItalianMediterranean diet. In particular, in Nicotera, the median MAI of the diet examined in 1996 has decreased to 2.8, while in Crevalcore it was reduced from 2.9 in 1965 to 2.2 in 1991 and in Montegiorgio from 5.6 in 1965 to 3.9 in 1991. In elderly men from Perugia the median value of MAI was decreased from 4.9 in 1976 to 3.2 in 1987, while in women from 3.1 to 2.6 [114]. However, many others nutritional indices are proposed to evaluate the efficacy of MD on healthy status. Cholesterol/Saturated Fat Index (CSI) is associated to atherogenicity grade, whereas the Atherogenic Index (AI) and Thrombogenic Index (TI) have been proposed in order to evaluate the possible link between diet and CHD [115]. The Mediterranean Diet Score (MDS) was proposed by Trichopoulou et al. in 1995 for the purpose of examine the relationship between MD and CHD in a random sample of 1159 Jewish people in Israel. The study showed that higher MDS correlated to lower risk of myocardial infarction, coronary bypass, angioplasty and any other cardiovascular disease [116]. In 2003 the MDS was modified by Trichopoulou et al., adding moderate fish consumption among the inclusion criteria. A two-points increase in the MDS with fish (t-MED) was associated with a reduction in CHD mortality by $33 \%$ [117-119] (Figure 1).

A US multiethnic population study has compared 4 diet-quality indexes, the Healthy Eating Index-2010 (HEI-2010), the Alternative HEI-2010 (AHEI-2010), the alternate Mediterranean Diet Score (aMED) and the Dietary Approaches to Stop Hypertension (DASH), in order to evaluate their effectiveness to predict the decrease risk of mortality for all causes. The authors suggested that high scores were inversely related to risk of mortality for CVD and cancer, reinforcing the concept that healthful diet is important to improve the quality of life and to provide a greater longevity [120].

In the 2000s, a Spanish multi-center, randomized trial of people at high risk for CVD, called PREDIMED (PREvenciòn con DIeta MEDiterrànea) study, showed that a MD supplemented with nuts reversed MetS more than a low-fat diet [121]. The study, conducted between October 2003 and December 2010, involved 7447 people divided into three subgroups: participants with MD supplemented with extra-virgin oil, participants with a MD supplemented with nuts and participants with low-fat diet (control group) [122]. The MD with extra-virgin oil after a median follow-up of 4.8 years, had reduced by $30 \%$ the rate of CVD events, whereas the MD with nuts had reduced by $28 \%$, compared with the control group. Moreover the MD, either supplemented with extra virgin olive oil or nuts, was not associated with the onset of MetS but only with its regression [123].

A recent meta-analysis conducted by Grosso et al. has linked the association between MD adherence and CVD incidence and mortality. They found an important decrease of incidence of CHD, myocardial infarction and stroke. The most protective effects are associated to higher consumption of olive oil, fruits, vegetables, legumes, nuts and moderate intake of wine (especially red wine) [124].

The "ATTICA study" assessed the effect of the MD on total antioxidant capacity in 3042 healthy subjects, selected from the Attica area of Greece. The adherence to MD was evaluated with a diet score. Total antioxidant capacity (TAC) was measured with colorimetric test on serum samples taken from the participants. The study has demonstrated that greater adherence to the MD is associated to higher TAC levels and low oxidized LDLcholesterol concentrations, suggesting a healthy role of MD on the cardiovascular system [125].

It's known that the adherence to MD and the change of unhealthy lifestyle have a great impact on the individual components of the MetS. In fact, the MD can be considered the first step in the treatment of NTCDs [126-128].

De Lorenzo et al had studied the impact of a moderately hypocaloric Mediterranean Diet (MHMD) on body composition and metabolic profile in 19 obese women. After the 2-months MHMD regimen, total fat mass and the segmental fat mass from trunk and legs were significantly decreased, while no significant loss of total and segmental lean body mass was observed. In the metabolic profile, a significant decrease of basal insulin, total and LDL-cholesterol, uric acid and fibrinogen was observed, while any change in fasting blood glucose, HDL-cholesterol and triglycerides was reported. This study has demonstrated that a MHMD with adequate nutritional indices based on foods and food combinations, was associated to a high 
effectiveness in term of compliance and safety, in particular to prevention of loss of fat-free mass and on metabolic parameters in obese women [115]. Andreoli et al. verified the effect of MHMD and physical activity on the body cell mass (BCM) and cardiovascular risk factors in obese women. After 2 and 4 months, the BCM has remained stable while the body composition has improved and major cardiovascular risk factors decreased [129, 130]. A recent paper had examined the effect of Italian Mediterranean Diet (IMD) and Italian Mediterranean Organic Diet (IMOD), in healthy subjects and in CKD patients, on body composition and on laboratory parameters. The aims of this study were to evaluate the impact of IMD and IMOD on decrease of cardiovascular risk factors and on the progression of renal disease. The authors demonstrated that the IMOD diet, according to "Nicotera Diet", was able to reduce the total Hcy, phosphorus and albuminuria levels in CKD patients and to ameliorate the cardiovascular risk profile in both population examined [131]. Another study of the same authors highlighted that IMD and IMOD diets represent a valid nutritional alternative intervention to low-protein diet in CKD patients on conservative therapy [132], since the low protein diet would seem to be a contributory cause of sarcopenia in these patients [133]. An interesting study of Di Daniele et al has shown that the IMD promotes weight loss and reduces the growing burden of cardiovascular risk factors that typifies patients with MetS. Specifically, a balanced hypocaloric IMD improves significantly systolic and diastolic blood pressure and fasting glucose in 80 white Italian subjects with MetS. Moreover the authors have observed a resolution of MetS in $52 \%$ of treated patients [134].

The apparent capacity of the traditional $\mathrm{MD}$ to reduce the risk of development and progression of CVD, cancer and degenerative diseases has been attributed, at least in part, to nutraceutical effect of micronutrients and compounds with capacity antithrombotic, anticancer and antioxidant. Carbohydrates are represented predominantly by starch, provided in large part from wheat (bread, pasta) and in smaller quantities from other cereals and pulses, while the proportion of sucrose, for the moderate consumption of sugar and sweets as such, is very low. Fish products and the extra virgin olive oil are mainly responsible for the contribution of fatty acids essential and oleic acid. The share of energy from oleic acid (monounsaturated) in the context of fatty acids is the largest one in the MD, which can also exceed $15 \%$ of the energy. Energy from saturated fatty acids (SFA) is not more than $7 \%$ of the total energy, so that the ratio polyunsaturated fatty acids / saturated is about $1: 1$. In the context of fatty acids essential, $\omega 3 / \omega 6$ ratio is very important. Fatty acids $\omega 3$ play an important role in the prevention and treatment not only of CVD but also cancer, rheumatoid arthritis, psoriasis and cataract. The daily $\omega 3$ recommended dose is $1,5 \mathrm{~g}$ in adult man and $1 \mathrm{~g}$ in adult woman $[135,136]$ (Table 3).

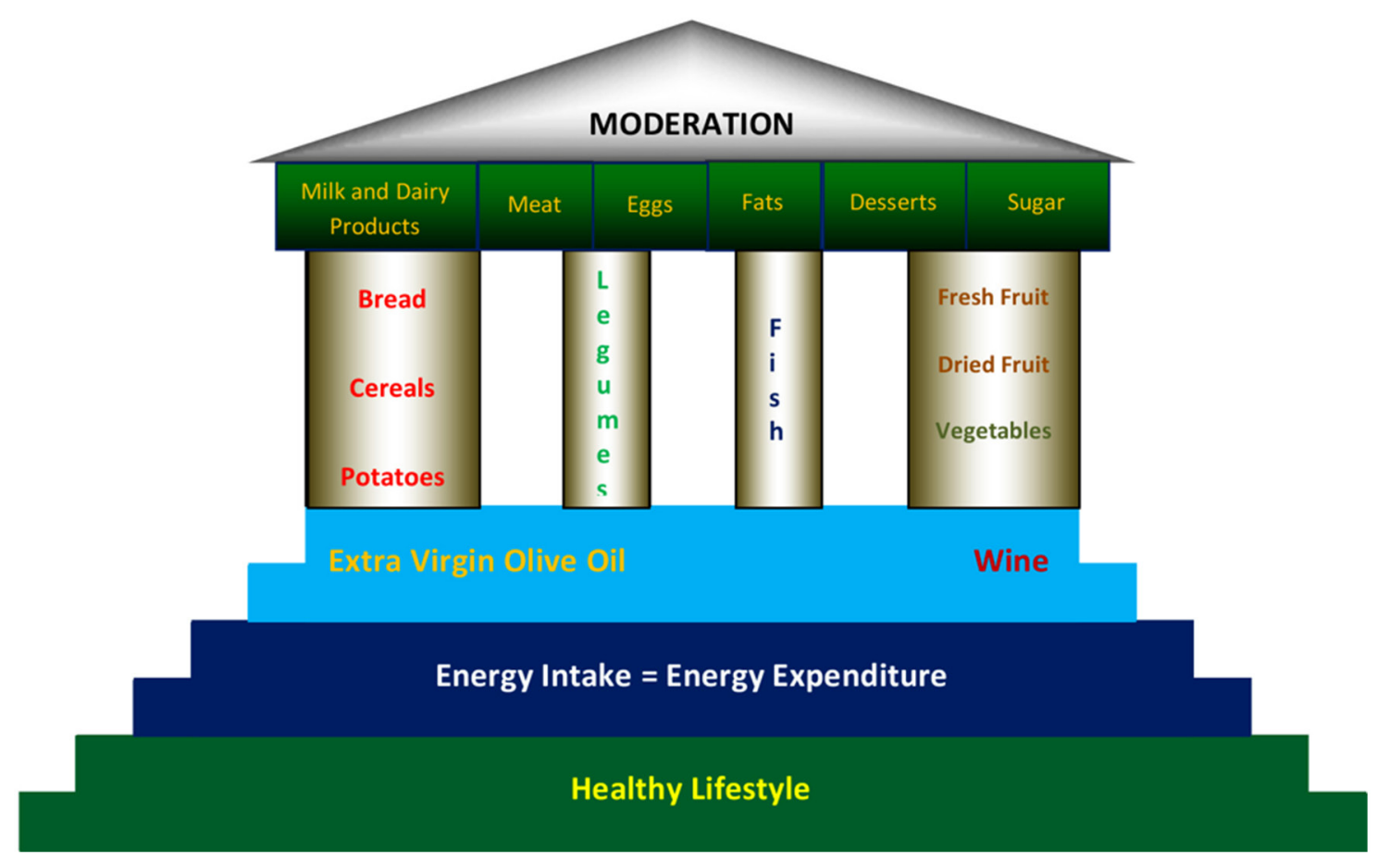

Figure 1: Representation of Mediterranean Diet by Paestum Temple Modified By De Lorenzo A, Fidanza F [89]. As shown in the figure, at the base of the Mediterranean style there is a healthy lifestyle, energy intake equal to the expenditure, extra virgin olive oil and wine. Within the eating habits must be more present: cereals, legumes, fish, fresh fruits, dried fruits and vegetables. While animal foods and simple sugars should be limited use. Moderation should be the focal point of the Mediterranean model. 
Table 3: Nutritional factors and targets

\begin{tabular}{|c|c|}
\hline Nutritional factors & Targets \\
\hline Total Fat & $15-30 \%$ \\
\hline Saturated fatty acids & $<10 \%$ \\
\hline Polinsatured fatty acids (PUFA) & $6-10 \%$ \\
\hline Polinsatured fatty acids n 3 (PUFA) & $5-8 \%$ \\
\hline Polinsatured fatty acids n 6 (PUFA) & $1-2 \%$ \\
\hline Trans fatty acids & $<1 \%$ \\
\hline Monoinsatured fatty acids (MUFA) & $*$ \\
\hline Total Carbohydrates & $55-75 \%$ \\
\hline Carbohydrates simple & $<10 \%$ \\
\hline Proteins & $10-15 \%$ \\
\hline Cholesterol & $<300 \mathrm{mg} /$ day \\
\hline Sodium Chloride & $<5 \mathrm{~g} /$ day $(<2 \mathrm{~g} /$ day $)$ \\
\hline Vegetables and Fruits & $\geq 400 \mathrm{~g} /$ day \\
\hline Flavonois & $>50 \mathrm{mg} / \mathrm{kg}$ \\
\hline Total dietary fiber & $>25-30 \mathrm{~g} /$ day \\
\hline Non-starch polysaccharides & $>20 \mathrm{~g} /$ day \\
\hline Mediterranean Adequacy Index (MAI) & $>6,5$ \\
\hline
\end{tabular}

Legend Table 3:

PUFA: Polinsatured fatty acids

MUFA: Monoinsatured fatty acids

MAI: Mediterranean Adequacy Index

Ranges of values for the nutritional targets in the general population according to Mediterranean Diet.

* This value is calculated as total fat - (satured fatty acids + polynsatured fatty acids + trans fatty acids)

In LIPGENE study, a large pan-European isocaloric dietary intervention study of MetS subjects, SFA have been replaced with MUFA or low-fat, high amount of complex carbohydrate, proving an effective improvement of insulin sensitivity only in patients whose habitual, preintervention dietary, fat intake was below the median ( $<36 \%$ energy from fat) [137]. Another study, called MUFA in Obesity (MUFObes), shows that MUFA rich diet improves insulin and glucose concentrations and reduces the risk of weight regain [138, 139]. In the KANWU (Kopio, Aahhus, Naples, Wollongon and Uppsala) Study, a change in the proportions of dietary fatty acid, decreasing SFA and increasing MUFA, leads to an improvement of insulin sensitivity [140].

The Mediterranean Diet is rich of $\omega-3$ PUFA, contained primarily in fish and seafood. Eicosapentaenoic acids (EPA, C20:5, n-3) and docosahexaenoic acid (DHA, C22:6, n-3) are the most important PUFA associated to cardio-protective effects [141].
Several intervention studies such as the "Gruppo Italiano per lo Studio della Sopravvivenza nell'Infarto Miocardico" (GISSI- Prevenzione trial and the Cardiovascular Health Study) have demonstrated that enhanced intake of EPA and DHA improves the risk of CHD [130-132]. The cardio-protective effects of EPA and DHA can be explained by their modulate $\mathrm{K}, \mathrm{Na}$, and $\mathrm{Ca}$ channels activities in myocardial cells, regulating myocyte electrical excitability and contractility. These effects are concentration-dependent [142, 143]. The role of n-6 PUFAs on human health is not clearly identified. However, both n-3 and n-6 PUFAs seem to be positive effect on cardiovascular disease, cancer, and depression in humans [144]. Many of the characteristic components of the traditional MD are known to have positive effects on the health status and they are called "functional foods". Carotenoids, folic acid and fibers would appear an important role in the prevention of CHD. Consumption vegetables, an important source of phytosterols, is associated with a reduction in the 
level of cholesterol in serum and cardiovascular risk. The increased consumption of fruits and vegetables, containing phytoestrogenic substances, may offer an alternative to hormonal therapy in menopausal women. In the gut, these residues are converted into estrogens, neutralizing the typical menopausal hormone deprivation. The polyphenols in red wine have antioxidant activity and cytoprotective action and induce a change in the lipoprotein profile, in platelet aggregation, and in redox mechanisms. The wine and other derivatives of red grapes rich in resveratrol (a polyphenol stilbene) determine a vasodilatory effect through the endothelium-dependent up-regulation of nitric oxide (NO) production, and have a significant antioxidant activity. Resveratrol, found in grape skins, is a potent anti-inflammatory by inhibiting iNOS, COX-2 and NF-kB. It was suggested that the histone acetylation, activated by NF-kB, could be suppressed by resveratrol [145]. The antioxidant capacity of red wine is higher than antioxidant capacity of white wine because is an excellent source of polyphenolic compounds such as phenolic acids, flavonoids [146]. Di Renzo et al have shown that the red wine combined with different meals (such as McDonald's Meal and a Mediterranean Meal) had a positive effect on ox-LDL and antioxidant gene expression (catalase, superoxide dismutase 2, sirtuins 2 and glutathione peroxidase 1). Thanks to its antioxidant capacity the red wine combined with MD may be an essential component of a holistic approach to prevent NTCDs linked to inflammation [147]. Several studies confirmed that flavonoids, especially resveratrol, inhibit pre-adipocyte proliferation, adipogenic differentiation and de novo lipogenesis [134, 148, 149]. In the PREDIMED population the moderate red wine consumption $(\geq 1$ drink/d) is associated with a lower prevalence of the MetS in patients at a high cardiovascular risk [150].

Another typical food of MD, besides the red wine, with antioxidant capacity is the tomato. Because the lycopene, a carotene phytochemical containing in tomato, induces the up-regulation of anti-oxidant enzymes activity (SOD, GPX and catalase) and shows anti-inflammatory properties and insulin-sensitizing [151]. Thanks its characteristics mitigates inflammation related to obesity. Ghavipour et al. have highlighted that daily supplementation with one glass of tomato juice decreases inflammatory cytokines such as TNF- $\alpha$, IL-6 and IL-8 after 20 days of assumption [152]. This result was confirmed by an another study of McEneny et al, in overweight subjects, in which a lycopene supplementation for 12 weeks decreased systemic levels of serum amyloid A [153]. Moreover, the daily tomato juice supplementation ameliorates also the body composition: a study on 30 young females with $\mathrm{BMI} \geq 20 \mathrm{~kg} / \mathrm{m}^{2}$ demonstrated that $280 \mathrm{ml} /$ day of tomato juice for two months significantly reduce body weight, body fat waist circumferences, BMI and serum levels of cholesterol, monocyte chemoattractant protein-1 (MCP-1) while significantly increased serum levels of adiponectin, triglycerides and lycopene [154]. The tomato and its products contain some natural compounds (such as chlorogenic, caffeic, ferulic and p-coumaric acids) that may inhibit platelet activation. These anti-platelet and anti-thrombotic activities of tomato were not modified by industrial tomato processing [155].

Another potential food promoting the positive effect of the MD is the extra-virgin olive oil, in fact its bioactive components would seem to have endothelium-protective and anti-oxidative properties [156]. A systematic review suggested that markers of inflammation such as $\mathrm{C}$-reactive protein, IL-6 and those related to endothelial-function such as flow mediated dilatation and E-selectine, are significantly ameliorated after supplementation of extravirgin olive oil [157]. The polyphenol intake is associated with lower cardiovascular mortality rates [158]. Extravirgin olive polyphenols have strong antioxidant proprieties as demonstrated in experimental studies [159]. In healthy subjects and in cardiovascular and dyslipidemic patients, the polyphenols contained in extra-virgin olive oil improved ischemic reactive hyperemia blood pressure and inflammatory status [160]. The presence of extravirgin olive oil in addition to raw vegetables increases the amount of phenolic components as oleuropein, pinoresinol, hydroxytyrosol and tyrosol and improves the contents of vegetable phenolics such as chlorogenic acid and rutin [161]. Moreover, olive oil is an excellent MUFA source and improves insulin sensitivity [162]. Estruch et al. compared the effects of MD, supplemented with either $11 \mathrm{~g} /$ week of virgin olive oil or $30 \mathrm{~g} /$ day of nuts and of low-fat diet on CVD markers. After 3 months of diet treatment, in patients with Mediterranean diet plus virgin olive oil or nuts was observed a reduction of oxLDL levels, whereas any change occurred in low-fat diet group [163]. Moreover, MD reduces IR, thanks to the high fibers content [164]. In vivo recent study has shown that a diet rich in soluble fibers $(20 \mathrm{~g} / 1000 \mathrm{kcal})$ and a decreased consumption of food items with a high glycemic index decreases the prevalence of MetS by improving blood pressure (BP) and IR $[165,166]$.

Recently the focus has shifted on caffeinated beverages, such as coffee and tea, and their association with the components of MetS. A study conducted on 1889 inhabitants living in Sicily has demonstrated that the intake of coffee and tea reduced the prevalence of MetS and improved the components of MetS, lowering triglycerides and fasting plasma glucose. The antioxidant properties of coffee and tea are associated to the content of polyphenols; in particular, the main polyphenols are the isomers of chlorogenic acid contained in coffee and the catechin chemical family contained in tea [167].

The high consumption of fresh fruits, in particular blueberries, is related to anti-inflammatory property. In the human and animal studies, polyphenolic anthocyanins (containing in blueberries) ameliorated systolic BP because of significantly increase of endothelial NO 
synthase levels and decrease of vasoconstriction, via nitric oxide-mediate pathway, and the reduction of renal oxidative stress $[168,169]$.

Basu et al. showed that the daily blueberries supplementation (about $350 \mathrm{~g}$ fresh blueberries or $50 \mathrm{~g}$ freeze-dried blueberries) decrease significantly plasma ox-LDL, malondialdehyde (MDA) and hydroxynonenal concentrations in subjects with MetS after eight weeks of supplementation compared to control group. Moreover, during the study a significantly reduction of systolic and diastolic BP was observed [170]. This result was confirmed by another study that has demonstrated that regular bilberry consumption may reduce low-grade inflammation (decrease serum high sensitivity CRP, IL-6, IL-12 and lipopolysaccharides) characteristic of MetS [171]. Also strawberries have high antioxidant capacity due to polyphenolic anthocyanins, fibers and several micronutrients content. A supplementation for 8 weeks of 4 cups freeze-dried strawberry beverage in patients with MetS, improved atherosclerosis risk factors, in particular decrease total and LDL-cholesterol and levels of vascular cell adhesion-1 (VCAM1) [172]. Flavonoid-rich foods intake is inversely associated with risk of death for CVD, CHD and all causes in postmenopausal US women, after 16 years of follow-up. In this study the authors considered both total flavonoids intake and seven subclasses of flavonols (anthocyanidin, flavanones, flavones, flavonols, isoflavones, flavan-3ols or monomers, proanthocyanidins). In the analyses of the food, apples and pears and red-wine are linked to a lower risk of CHD and CVD. Grapefruit, major source of flavonones, is also associated with a decrease risk of CHD mortality [173].

The healthy properties of the MD cannot be limited to any single nutrient, food or food component, but they have to be extended to the entire meal pattern and lifestyle (Table 4).

\section{MEDITERRANEAN DIET AND CANCER}

The cancer, actually, is considered the second cause of death in the world after cardiovascular diseases [174].

Obesity is related to a higher risk of cancer because of chronic low-grade inflammation, induced by proinflammatory cytokines released by adipose tissue. Data indicated that inflammation is linked to oxidative stress. In fact Reactive Oxygen Species (ROS) are continuously produced by cellular and oxidative metabolism, and accumulation of ROS may cause oxidative damage and promote inflammatory reactions [175]. During carcinogenesis, immune and inflammation response produces cytokines and chemokines that facilitate cancer development, angiogenesis and modify tumor microenvironment [176]. These cytokines and chemokines can change expression of important transcription factors, including NF-kB, STAT-3, beta-catenin, p53, HIF-1 NFAT, responsible for cell response [177]. Among there, NF$\mathrm{kB}$ is considered the crucial regulator in tumorigenesis, linking ageing, obesity, inflammation, and cancer [178].

Cancer cell shows a clear altered metabolism, with distinct usage of the energy versus the biosynthetic pathways [179-184]. A large number of studies have evaluated the ROS in cancer cells [185-196] and their relationship with the mitochondrial activity [197-208].

This energy and anabolic change implies also a significant interplay with autophagy [209-212], a pathway that strongly affects cancer progression, as well as distinct signalling pathways, such as for example JNK [212, 213], the p53 family [214-221] death receptors, as well as mechanisms $[222,223]$.

The diet and the natural antioxidants, in particular, play an important natural antioxidants play an important role on these metabolic pathways affecting cancer progression [224-228]. In keeping, several dietary supplements can offer ancillary support in cancer treatment [229-235].

The MD has a preventive action on cancer, because of the anti-proliferative and anti-apoptotic effects on cancer cell [236].

Noto et al. have demonstrated that, in a Mediterranean population, metabolic disturbances (obesity and MetS) are predictive of cancer in a 25 years follow up [237]. Epidemiological studies assessed that 640 million adults in 2014 and 110 million children and adolescents in 2013 were obese. The obesity-related cancer represents up to $9 \%$ of cancer among women in North America, Europe and the Middle East. In 2013, 4.5 million deaths worldwide were related to overweight and obesity [238]. The International Agency for Research on Cancer (IARC) working group concluded that excess of body fatness increases cancer risk, especially for colon, rectum, gastric cardia, liver, gallbladder, pancreas, kidney cancers and esophageal adenocarcinoma, as later confirmed by Beavis et al. in 2016 [239, 240].

In particular, cancer's risk increased from 1.2 to 1.5 in overweight individuals and from 1.5 to 1.8 in obesity people, especially for colon, gastric cardia, liver, gallbladder, pancreas and kidney cancers, while the relative risk for esophageal adenocarcinoma was up to 4.8 in patients with BMI $\geq 40 \mathrm{~kg} / \mathrm{m}^{2}$ [241-244].

Populations living in the area of Mediterranean Sea showed a decrease incidence of cancer compared with those living in regions of North Europe or US, this has been attributed to healthier dietary habits [245]. In the past decade, several reports indicated a protective role of MD towards neoplastic diseases. In particular, a meta-analysis study by Sofi and colleagues reported that MD is responsible of $6 \%$ reduction of cancer death/ incidence [246]. An updated study, done on a very large cohort (335,873 subjects of the European Prospective Investigation Into Cancer and Nutrition), reported a lower cancer risk in subjects following MD [247]. Nowadays, several epidemiological studies focused on the association 
Table 4: List of studies about Mediterranean Diet

\begin{tabular}{|c|c|c|c|c|c|}
\hline Reference & Population & Follow- & $N$ & Outcome & FINDINGS \\
\hline Country & & up & Age & & \\
\hline Years & & & range & & \\
\hline
\end{tabular}

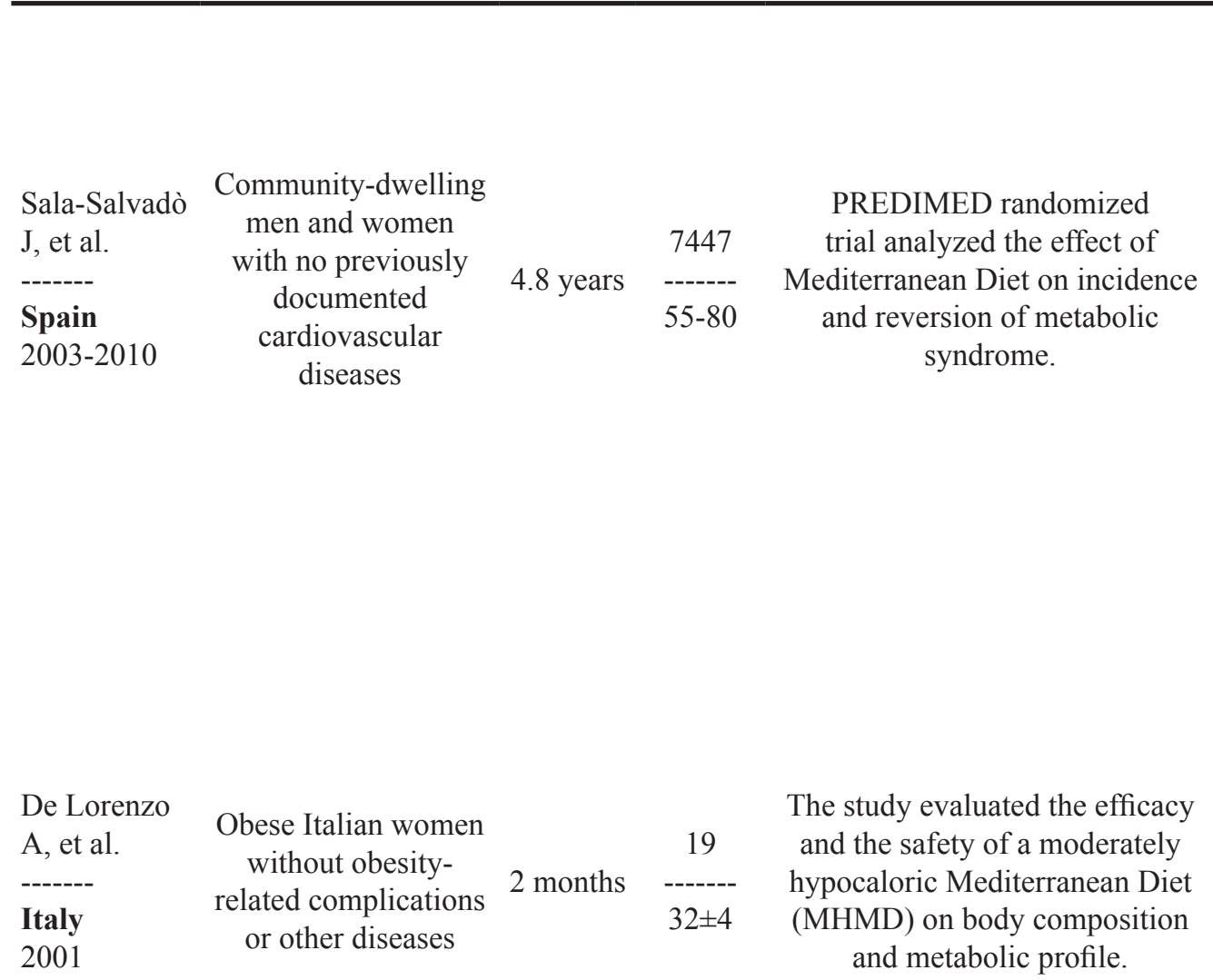

The Mediterranean Diet with extra-virgin oil after a median follow-up of 4.8 years, had reduced by $30 \%$ the rate of CVD events. The Mediterranean Diet with nuts had reduced by $28 \%$. The Mediterranean diet, either supplemented with extra virgin olive oil or nuts, was not associated with the onset of metabolic syndrome but only with its regression.

Total fat mass and segmental fat mass from trunk and legs were significantly decreased, while no significant loss of total and segmental lean body mass was observed. In the metabolic profile, a significant decrease of basal insulin, total and LDL-cholesterol, uric acid and fibrinogen was observed, while any change in fasting blood glucose, HDL-cholesterol and triglycerides was reported.

Andreoli A, et al.

47

Obese women

4 months

$39.7 \pm 13$

Italy

2008

De Lorenzo

A., et al.

Caucasian Italian men

(100 healthy male

Italy

2010 individuals and 50

male CKD patients)
14 days
150

$------$

30-65
The study evaluated the effects of a moderately hypoenergetic Mediterranean diet (MHMD) and exercise program on body cell mass (BCM) and cardiovascular disease risk factors in obese women.

The aim was to verify the effect of Italian Mediterranean Diet (IMD) on body composition and biochemical parameters in healthy individuals and in Chronic Kidney

Disease (CKD) patients, in order to decrease cardiovascular disease (CVD) risk factor and the progression of renal diseases.
MHMD and exercise program for 4 month preserved BCM and improved cardiovascular disease risk factors in obese women

The IMOD diet, according to "Nicotera Diet", was able to reduce the total homocysteine, phosphorus and albuminuria levels in CKD patients and to ameliorate the cardiovascular risk profile in both population examined

(Continued) 


\begin{tabular}{|c|c|c|c|c|c|}
\hline Reference & Population & Follow- & $N$ & Outcome & FINDINGS \\
\hline Country & & $u p$ & Age & & \\
\hline Years & & & range & & \\
\hline
\end{tabular}

\begin{tabular}{|c|c|c|c|}
\hline $\begin{array}{l}\text { Di Daniele } \\
\text { N, et al. }\end{array}$ & $\begin{array}{l}\text { Caucasian Italian men } \\
\text { with CKD and stable }\end{array}$ & 28 days & 40 \\
\hline $\begin{array}{l}\text { Italy } \\
2014\end{array}$ & renal function & & $42-54$ \\
\hline $\begin{array}{l}\text { Di Renzo L, } \\
\text { et al. }\end{array}$ & $\begin{array}{l}\text { Healthy volunteers } \\
\text { aged } 18-65 \text { years and }\end{array}$ & 18 weeks & 24 \\
\hline $\begin{array}{l}\text { Italy } \\
2014\end{array}$ & $\mathrm{BMI} \geq 19 \mathrm{~kg} / \mathrm{m}^{2}$ & & $18-65$ \\
\hline
\end{tabular}

The aim was to explore the effect of an Italian Mediterranean organic diet (IMOD) versus low-protein diet (LPD) in chronic kidney diseases (CKD) patients, according to patients' carrier status for the methylenetetrahydrofolate reductase (MTHFR) C677T polymorphism.

The study evaluated if the consumption of a Mc Donald's Meal (McD) and a Mediterranean Meal (MM) with and without the addiction of red wine, reduces oxidized (ox-) LDL and the expression of oxidative and inflammatory genes.

Ghavipour M, et al.

Iran

Overweight or obese female students

20 days

106 -----20-40

2012
Mc Eneny J, et al.

-------

UK

2012

Li YF, et al.

Taiwan

2015
Moderately overweight individuals.

12 weeks 54 -----middleaged

This study examined lycopene's ability to lower systemic and high-density lipoprotein (HDL)associated inflammation in moderately overweight middleaged subjects.

This study showed the effect of tomato juice's supplementation on indices linked to metabolic health and adipokine profiles in generally healthy people.
IMD and IMOD diets represent a valid nutritional alternative intervention to low-protein diet in chronic kidney disease (CKD) patients on conservative therapy.

When red wine is associated with $\mathrm{McD}$ or MM, values of ox-LDL are lowered, the expression of antioxidant genes is increased, while CCL5 expression is decreased.

Tomato juice reduces inflammation in overweight and obese females. Serum concentrations of IL-8 and TNF- $\alpha$ decreased significantly in overweight subjects. Among obese subjects, serum IL-6 concentration was decreased in the intervention group compared with the control group, with no differences

in IL- 8 and TNF- $\alpha$ observed.

A lycopene supplementation for 12 weeks decreased systemic levels of serum amyloid A.

Daily tomato juice supplementation reduces waist circumference, as well as serum cholesterol and inflammatory adipokine levels in young healthy women and these results are unrelated to body fat changes.

(Continued) 


\begin{tabular}{|c|c|c|c|c|}
\hline $\begin{array}{l}\text { Reference } \\
\text { Country } \\
\text { Years }\end{array}$ & Population & $\begin{array}{c}\text { Follow- } \\
\text { up }\end{array}$ & $\begin{array}{l}N \\
\text { Age } \\
\text { range }\end{array}$ & Outcome \\
\hline $\begin{array}{l}\text { Pitsavos C, } \\
\text { et al. } \\
\text {----- } \\
\text { Greece } \\
2005\end{array}$ & $\begin{array}{l}\text { Random sample with } \\
\text { no clinical evidence } \\
\text { of cardiovascular } \\
\text { disease }\end{array}$ & 1 year & $\begin{array}{l}3042 \\
----- \\
18-89\end{array}$ & $\begin{array}{l}\text { "the ATTICA study" assessed } \\
\text { the effect of the MD on total } \\
\text { antioxidant capacity (TAC) }\end{array}$ \\
\hline $\begin{array}{l}\text { Tierney, } \\
\text { A.C.; et al. } \\
-\mathbf{E U} \\
2011\end{array}$ & MetS subjects & 12 weeks & $\begin{array}{c}417 \\
----- \\
\text { Mean } \\
54.9\end{array}$ & $\begin{array}{c}\text { In LIPGENE study, a large } \\
\text { pan-European isocaloric dietary } \\
\text { intervention study of MetS } \\
\text { subjects, saturated fatty acid } \\
\text { (SFA) have been replaced with } \\
\text { MUFA or low-fat, high complex } \\
\text { carbohydrate. }\end{array}$ \\
\hline
\end{tabular}

Vessby B,

et al. \&

KANWU

Study

------

Sweden

2001

GISSI-

Prevenzione

trial.

Patients surviving

recent ( $\leq 3$ months) $3-5$ years

-------

Italy

myocardial infarction

162

Healthy subjects

3 months

$30-65$

1999

Di Daniele

$\mathrm{N}$, et al.

Italy

2013

Fitò M, et al.

Spain

2003-2004

Cuenca-

García M,

et al.

------

Spain

1987-1999
Subjects with high cardiovascular risk

3 months
White Italian subjects with MS

6 months
80

$48,7 \pm$

13

$50-80$ men and women 12 years $20-84$

The aim was to evaluate whether a change in dietary fat quality could improve insulin action.

The study investigated the effects of foods rich in vitamin $\mathrm{E}$ ( $\alpha$-tocopherol) and n-3 polyunsaturated fatty acids (PUFA) in patients who had myocardial infarction.

The aim was to evaluate the benefits of dietary intervention based on a typical IMD on body composition, cardiometabolic

changes and reduction in cardiovascular disease in patients with MS

The aim was to verify the efficacy 372 of the Mediterranean diet (MD) on the primary prevention of 55-80 coronary heart disease in patients with high cardiovascular risk.

The study examined the association between three predefined dietary indices (Ideal 12449 Diet Index, Diet Quality Index, Middle-aged healthy 12 years $\quad------\quad$ and Mediterranean Diet Score) and both cardiovascular disease (CVD) risk factors and long-term mortality in adult Aerobics Center Longitudinal Study's participants.

Greater adherence to the MD is associated to higher TAC levels and low oxidized LDL-cholesterol concentrations.

Improvement of insulin sensitivity only in patients whose habitual pre-intervention dietary fat intake was below the median $(<36 \%$ energy from fat).

A decrease of saturated fatty acid and an increase of monounsaturated fatty acid, improves insulin sensitivity but has no effect on insulin secretion.

Dietary supplementation with n-3 PUFA led to a clinically important and satistically significant benefit. Vitamin E had no benefit.

The MS was resolved in $52 \%$ of the patients.

Significant improvements in systolic and diastolic blood pressure and fasting glucose occurred.

After 3 months of Mediterranean Diet, individuals at high cardiovascular showed significant reductions in cellular lipid levels and LDL oxidation.

Higher Ideal Diet Index, Diet Quality Index, and Mediterranean

Diet Score scores were significantly linked to lower body mass index, cholesterol and glucose levels, and diastolic blood pressure, and higher cardiorespiratory fitness. 


\begin{tabular}{|c|c|c|c|c|c|}
\hline $\begin{array}{l}\text { Reference } \\
\text { Country } \\
\text { Years } \\
\end{array}$ & Population & $\begin{array}{l}\text { Follow- } \\
\text { up }\end{array}$ & $\begin{array}{c}N \\
\text { Age } \\
\text { range }\end{array}$ & Outcome & FINDINGS \\
\hline $\begin{array}{l}\text { Ruano J, et } \\
\text { al. } \\
\text {------ } \\
\text { Spain } \\
2005\end{array}$ & $\begin{array}{c}\text { Hypercholesterolemic } \\
\text { volunteers }\end{array}$ & 2 hours & $\begin{array}{c}21 \\
------ \\
53-68\end{array}$ & $\begin{array}{l}\text { The aim of this study was } \\
\text { to evaluate the effects of the } \\
\text { phenolic content of virgin olive } \\
\text { oil on endothelial reactivity. }\end{array}$ & $\begin{array}{l}\text { The intake of the } \\
\text { polyphenol-rich breakfast } \\
\text { was associated with a } \\
\text { greater increase of nitrates/ } \\
\text { nitritis ratio and lower } \\
\text { lipoperoxides and 8-epi } \\
\text { prostaglandin-F2alpha } \\
\text { levels. }\end{array}$ \\
\hline $\begin{array}{l}\text { Grosso G, } \\
\text { et al. } \\
\text {----- } \\
\text { Italy } \\
2014\end{array}$ & $\begin{array}{l}\text { Subjects with or } \\
\text { without metabolic } \\
\text { syndrome }\end{array}$ & 1 year & $\begin{array}{c}1889 \\
----- \\
\text { Mean } \\
50.2\end{array}$ & $\begin{array}{l}\text { The study investigated the } \\
\text { relationship between the } \\
\text { beverages containing caffeine } \\
\text { and the components of metabolic } \\
\text { syndrome. }\end{array}$ & $\begin{array}{c}\text { Coffee and tea } \\
\text { consumption was } \\
\text { significantly associated } \\
\text { with reduced odds of } \\
\text { MS; however, no direct } \\
\text { association between } \\
\text { caffeine intake and } \\
\text { MS components was } \\
\text { evaluated. }\end{array}$ \\
\hline \begin{tabular}{l} 
Basu A, et al. \\
\hdashline--- \\
US \\
2010
\end{tabular} & $\begin{array}{l}\text { Men and women with } \\
\text { metabolic syndrome }\end{array}$ & 8 weeks & $\begin{array}{c}48 \\
----- \\
50 \pm 3\end{array}$ & $\begin{array}{l}\text { The study aimed to evaluate } \\
\text { the effects of blueberry } \\
\text { supplementation on features } \\
\text { of metabolic syndrome, lipid } \\
\text { peroxidation, and inflammation in } \\
\text { obese men and women. }\end{array}$ & $\begin{array}{c}\text { The blueberry } \\
\text { supplementation decreases } \\
\text { systolic and diastolic } \\
\text { blood pressures, whereas } \\
\text { the serum glucose } \\
\text { concentration and lipid } \\
\text { profiles were not affected. }\end{array}$ \\
\hline $\begin{array}{l}\text { Kolehmainen } \\
\text { M et al. } \\
----- \\
\text { Finland } \\
2012\end{array}$ & $\begin{array}{c}\text { Subjects with } \\
\text { metabolic syndrome }\end{array}$ & 8 weeks & $\begin{array}{c}27 \\
----- \\
53 \pm 6\end{array}$ & $\begin{array}{l}\text { The aim was to study the impact } \\
\text { of bilberries on inflammation } \\
\text { and gene expression profile in } \\
\text { peripheral blood mononuclear } \\
\text { cells. }\end{array}$ & $\begin{array}{l}\text { Blueberry supplementation } \\
\text { decreases serum high- } \\
\text { sensitivity C-reactive } \\
\text { protein, IL-6, IL-12, } \\
\text { and LPS concentration, } \\
\text { demonstrating a decrease } \\
\text { of cardiometabolic risk in } \\
\text { long term. }\end{array}$ \\
\hline $\begin{array}{l}\text { Basu A et al. } \\
-\mathbf{U S} \\
2010\end{array}$ & $\begin{array}{c}\text { Subjects with } \\
\text { metabolic syndrome }\end{array}$ & 8 weeks & $\begin{array}{c}27 \\
----- \\
47 \pm 3\end{array}$ & $\begin{array}{l}\text { The aim was to verify if a freeze- } \\
\text { dried strawberry supplementation } \\
\text { can improve blood pressure, } \\
\text { impaired glucose, dyslipidemia, } \\
\text { or circulating adhesion molecules } \\
\text { in obese subjects with metabolic } \\
\text { syndrome. }\end{array}$ & $\begin{array}{c}\text { A short-term } \\
\text { supplementation with } \\
4 \text { cups of freeze-dried } \\
\text { strawberry beverage } \\
\text { improve selected } \\
\text { atherosclerotic risk factors, } \\
\text { including dyslipidemia } \\
\text { and circulating adhesion } \\
\text { molecules in subjects with } \\
\text { metabolic syndrome. }\end{array}$ \\
\hline
\end{tabular}

\section{Legend Table 4:}

CVD: cardiovascular diseases

MHMD: moderately hypocaloric Mediterranean Diet

LDL: Low density lipopretein

HDL: high density liporptein

BCM: Body cellular mass

(Continued) 
IMD: Italian Mediterranean Diet

IMOD: Italian Mediterranean Organic Diet

CKD: Chronic kidney disease

LPD: Low protein diet

MTHFR: methylenetetrahydrofolate reductase

McD: Mc Donald's Meal

MM: Medierranean Meal

CCL5:Chemokine (C-C motif) ligand 5

IL-8: interleukin-8

TNF- $\alpha$ : tumor necrosis factor alpha

IL-6: interleukin-6

MD: Mediterranean Diet

TAC: Total antioxidant capacity

MetS: Metabolic Syndrome

SFA: Saturated Fatty Acid

MUFA: Monoinsaturated Fatty Acids

MS: Metabolic Syndrome

IL-12: interleukin-12

LPS: Lipopolysaccharide

The most important studies in the world about the impact of Mediterranean Diet on cardiovascular risk factors: findings suggest the protective role of MD.

of MD and specific type of cancers (breast and colorectal cancers).

The worst cancer in women is breast cancer, which accounts for over $25 \%$ of all female cancers. Estrogen has a key role in the pathogenesis and progression of this cancer. The MeDiet study investigated the effect of the MD on the levels of endogenous estrogens in healthy postmenopausal women [248]. The women enrolled were divided into two different groups: the first group was treated with the MD for six months, while the control group continued the current diet. Urine samples were examined in order to assess the levels of estrogen, which reflect its intra-tissutal content [249] The majority of urinary estrogen is represented by hydroxy and methoxy derivatives of estradiol (E2) and estriol (E3). The study revealed that the group receiving $\mathrm{MD}$ had reduced levels of hydroxy and keto derivatives of E2 and E3, known as 2-hydroxy E2 (2OHE2), 17EpiE3 and 16KetoE2, respectively 80,70 and $27 \%$ after six months, while they were unchanged in the control group. The study confirmed the protective role of the MD on cancer development, acting on estrogen metabolism.

Regarding to the colon rectal cancer, a recent study [250] showed that this neoplasia is the third most common in US. The authors associated colon rectal cancer risk, MD Score (MDS) and the Healthy Eating Index (HEI) furthermore; they define a novel Dietary Inflammatory Index (DII). Comparing different published studies (US and European patients), the authors established that higher MDSs were associated with lower colorectal cancer risk (8-54\%), as well as higher HEI scores were associated with lower colorectal cancer risk (20-56\%). On the other hands, pro-inflammatory diets were associated with a $12-65 \%$ higher colorectal cancer risk compared with more anti-inflammatory diets in studies that used the DII [250]. The latter result is very interesting as unresolved inflammation, unrelated to infections, observed in obesity, can contribute to carcinogenesis as observed in Barrett's metaplasia, chronic pancreatitis or esophagitis [251].

The MD contributes to the prevention of colorectal cancer through a high intake of fiber. Barera et al. have highlighted the nutraceutical effects of $\beta$-glucans, which seem to reduce low-density lipoprotein cholesterol (LDL), IL-6 and advanced glycation end-product (AGE) levels. They are also linked to colon cancer prevention [252].

The MD is able to reduce gastric cancer's incidence and mortality in the South areas of selected Mediterranean country, such as France, Greece and Italy when compared 
with the North areas of the same countries. Higher adherence to MD lower up of $20 \%$ the incidence of all gastric cancers [253-255].

The beneficial role of MD has also been confirmed in a large case-control study in Italy. The authors found that an enhanced adherence to MD (high consumption of fruit, vegetables and legumes) reduced risk of both oral cavity and pharynx cancer and larynx cancer [256].

Head and neck cancers are currently the sixth cause of death in the world; however, as confirmed by Bosetti et al., a greater adherence to the MD reduces the risk of oral, laryngeal and pharyngeal cancer (by 23 and 29\%, respectively) [257].

Jacobs et al. have suggested that consumption of whole grain (bran, germ, endosperm) $\geq 4$ times / week reduces the risk of cancer by $40 \%$ compared to controls, while the Continuous Update Project has determined that the intake of non-starchy vegetables and fruits lowers the risk of mouth, pharynx, larynx, esophagus and stomach cancers [258, 259].

On the other hand, the intake of refined cereal grains (bread, pasta or rice) increase the risk of upper digestive tract, stomach, colorectal, breast and thyroid cancer [260].

Another pivotal food of the MD is pulses. Thanks to their content in tannins, saponins, protease inhibitor and phytic acid, legumes play an important anti-cancer role [261].
Even the consumption of nuts was associated to the reduction of cancer's risk, in particular for those of the digestive tract. The protective role of nuts comes from their content of ellagic acid, anacardic acids, genistein, resveratrol and phytic acid [262]. The consumption of peanut products $\geq 2$ / week was associated with $58 \%$ reduction of colorectal cancer risk in Taiwan women [263].

According to IARC, ethanol was positively correlated to cancers (e.g. mouth, pharynx, larynx, oesophagus, colorectal in men, breast in pre and postmenopause). The Continuous Update Project also confirmed the carcinogen effect of alcohol in liver and colorectal cancers [264]. However, the studies on MD show that a moderately intake of red wine in premenopause women reduced breast cancer risk, inhibiting the conversion of androgens to estrogens, catalyzing by aromatase [113, 265] This effect is due to polyphenols content of red wine, including flavonoids (anthocyanins and flavan-3-ols) and non-flavonoids (resveratrol, cinnamates and gallic acid [266].

The role of main components of the MD in the prevention of several cancers type has been recently reviewed in several works [245, 267, 268, 269] (Figure 2).

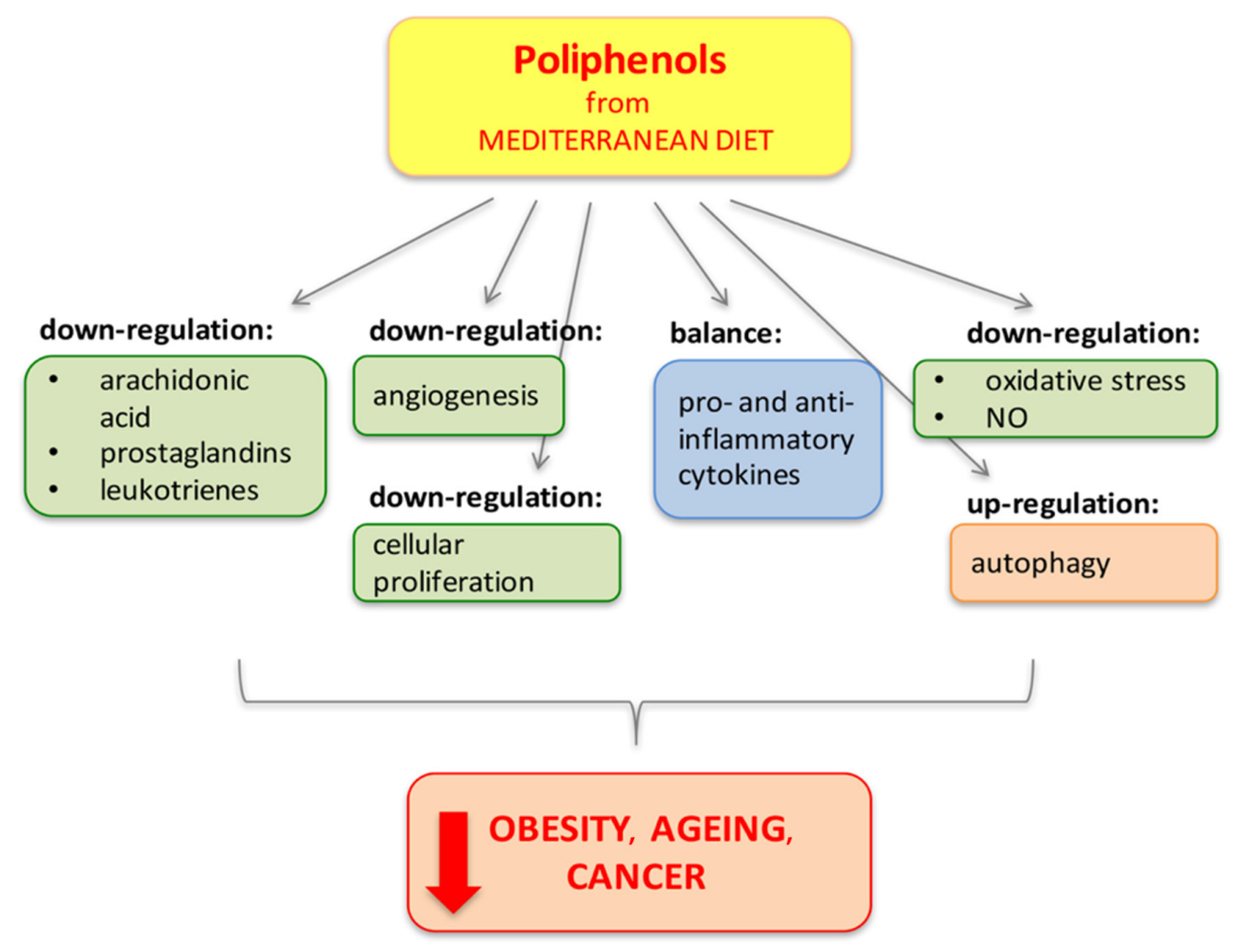

Figure 2: Polyphenols from Mediterranean Diet. Polyphenols protect and reduce inflammation by different pathways (through mechanisms of down-regulation, balance and up-regulation) preventing obesity, cancer and age-related diseases, in which inflammation has an important pathological role [240]. 


\section{MEDITERRANEAN DIET AND LONGEVITY}

Cellular aging consists in a loss of cellular physiological functions, which occurs gradually over time. The most important biological marker of this process is represented by telomere shortening that affects life expectancy and increases the individual susceptibility to the development of chronic diseases [270, 271]. Eating habits and metabolic factors (particularly an increased visceral adipose tissue and circulating glucose levels) cause a faster shortening of telomeres and a reduction telomerase activity, suggesting a key role of the environment in cellular senescence [272]. Several survival-population studies have demonstrated that a diet rich in fruits, vegetables, fish and low in fat foods, is correlated to lower incidence of chronic diseases and higher survival $[273,274]$. In particular, a greater adherence to MD (expressed as higher MDS) was related to longer leukocyte telomere length, higher telomerase activity and lower plasmatic level of pro-inflammatory cytokines (such as IL- 6 and TNF- $\alpha$ ) and a reduction of oxidative stress [275].

Tiainen et al. reported that fruit and vegetables consumption was positively linked to leukocyte telomere length in women aged 57-70 years, but not in men with the same age [277].

The MDS, together with the Mediterranean Adequacy Index (MDI) and the Healthy Diet Indicator (HDI), were studied during the Healthy Ageing: a European longitudinal study (HALE) that included men and women from ten European countries. The subjects were followed for a 10 years-time observation. The study has confirmed the protective role of MD for elderly subjects with and without baseline chronic diseases [277]. A recent prospective study involving 4676 healthy women has demonstrated the relationship between adherence to the MD and telomere length in cells, supporting the concept of the benefits of MD to promote health status and longevity. Any association was noted between the individual MD components and longevity, but was supposed a synergy effect among the nutrients rich foods included in MD [278]. In general, subjects who adhere to the traditional MD have a longer life - span [275]. Another study confirmed that higher adherence to MD in older adults in the United-States and Israel is linked to better cognitive and physical functions. In fact, in this subjects were detected a faster walking speed and fewer disabilities [279]. The PREDIMED trial reports how the MD supplemented with olive oil (1 1/wk) or mixed nuts $(30 \mathrm{~g} / \mathrm{d})$ is linked to lower cognitive decline, evaluated through standardized neuropsychological tests in older populations [280]. In a Greek population cohort study, Trichopoulou et coworkers demonstrated for the first time that higher degree of adherence to MD was correlated with a reduction in total mortality; an increase of two point of
MDS was associated with a diminution of $25 \%$ mortality of all-causes. This reduction was more evident for CVD respect to cancer [281]. A subsequent meta-analysis of prospective studies confirmed a significant protective role of MD against major chronic degenerative disease. In fact, an increase of two-points of MDS induced 8\% reduction of death from any causes, a 10\% reduction from death and/ or incidence of cardio and cerebro-vascular disease and $13 \%$ reduction of neuro-degenerative disease [246].

Another paper has compared the effects of three different diets, following for four weeks, on cellular senescence: saturated fatty acids diet, a low-fat/high carbohydrate diet and MD enriched in MUFA. The study concluded that MD prevents endothelial-cells aging and decreased intracellular oxidative stress, cellular apoptosis and telomere shortening. Moreover, the MD was associated with an improvement in the regenerative capacity of endothelium, in comparison with other diets $[282,283]$. In order to explain the role of MD on telomere lengths could be considered the protective action of olive oil (OO), in particular virgin olive oil polyphenols, on mitochondrial and nuclear DNA against oxidative stress. The OO induces important epigenetic changes through its MUFA content and polyphenolic compounds; in fact, $\mathrm{OO}$ can prevent and palliate some aging-associated disease such as diabetes [284].

The OO protective effect on aging is confirmed by another study that has evaluated the bioactivity of $\mathrm{OO}$ compounds on multipotential mesenchymal stem cell (MSC) progenitor differentiation. In fact, osteoblasts and adipocytes derive from the same MSC. Santiago-Mora et al. have demonstrated that oleuropein, one of the most important $\mathrm{OO}$ compounds, enhances osteoblastogenesis and inhibits the main adipogenesis regulators, as PPAR- $\gamma 2$, lowering the incidence of osteoporosis [285]. Furthermore, the phenolic compound oleocantale has the same antiinflammatory effects of ibuprofen, the most common non-steroidal anti-inflammatory. In fact the OO intake decreases inflammation and consequently aging [286].

The benefits of MD are evident in the prevention and slowing the progression of chronic degenerative diseases. A meta-analysis highlighted that both men and women who nearest eating habits to MD have a reduced risk of about $10-20 \%$ to die for CVD, cancer and other any causes. The MD is significantly inversely associated with both systolic and diastolic BP. A prospective study on 41358 Spanish adult subjects, during 6.5 years of follow-up, evaluated the possible relationship between dietary factors and total mortality. The authors showed that high intakes of fresh fruit and vegetables are associated with decreased mortality, probably related to the high concentration on vitamin $\mathrm{C}$, provitamin $\mathrm{A}$, carotenoids and lycopene. Antioxidant capacity of vitamin $\mathrm{C}$ and provitamin A partly explain this effect on mortality [287]. The MD, poor in refined sugar and animal proteins, reduces the activity of mTOR and insulin/IGF-1 pathways, 
lowering the risk of age-related diseases, promoting successful aging and longevity [288].

To confirm the protective role of the MD, the Lion Diet Heart Study has shown a reduction in secondary cardiac events, including death and non-fatal myocardial infarction, after a first myocardial infarction. This protective effect remains at least four years after the first heart attack, independent of main cardiovascular risk factors, such as hypertension and dyslipidemia [289-291].

The benefit effect of MD has confirmed also on elderly non-smoking people. In this study 161 nonsmoking individuals, aged 65-90, were separated into two different groups: the first were $65-80$ years, the latter $>80$ years. The study has demonstrated that the total diet score, based on 8 main components of $\mathrm{MD}$, is positivity associated to higher longevity in patients less 80 years, but not in those greater than 80 . The authors have noted also that higher albumin concentration is linked to lower mortality [292].

The MD includes a high significantly quantity of foods rich in antioxidant compounds, which can help explain its many benefits. The extra virgin olive oil, vegetables, fresh fruits, nuts, wine and fish, contain molecules with anti-oxidants and anti-inflammatory properties, as monounsaturated fatty acids, fatty acids omega 3, polyphenols, flavonoids, phytosterols, vitamins, antioxidants, minerals and micronutrients. These factors act on longevity and slow the development of chronic diseases associated with aging [293].

MD effect on telomere length makes itself a powerful anti-aging tool.

\section{CONCLUSION}

MetS is characterized by a cluster of metabolic alterations that can conduce to NTCDs. Several epidemiological, clinical and experimental studies suggested that both the increased quantity and the dysfunctional quality of AT, called "adiposopathy", cause the onset of chronic metabolic diseases and increases cancer incidence. The diet and lifestyle are gaining an increasingly important role, both for the treatment and the prevention of NTCDs. Early population diet-therapy intervention and the study of genetic polymorphism allow the prevention and slow the progression of chronic degenerative diseases (Table 2 and 3, Figure 2). In 2010, the UNESCO proclaimed the MD as "World Cultural Heritage". This diet represents a behavioural model, a "way of life", that can ensure longer life expectancy and improve quality of life itself.

\section{Abbreviations}

a MED: alternate Mediterranean Diet Score; ACSL1: long-chain acyl CoA synthetase 1; AHEI-2010: the Alternative HEI-2010; AI: Atherogenic Index; AT:
Adipose tissue; ATGL: fatty triglyceride lipase; BAT: brown adipose tissue; BCM: body cell mass; BMD: bone mineral density; BP: blood pressure; CAPN10: Calpain 10; CHD: cardiac heart disease; CKD: chronic kidney disease; COX: ciclo-oxigenase; CSF1: colony stimulating factor-1; CSI: Cholesterol/Saturated Fat Index; CVD: cardiovascular diseases; DASH: Dietary Approaches to Stop Hypertension; DHA: docosahexaenoic acid; DII: Dietary Inflammatory Index; e-GFR: estimated glomerular filtration rate; EAT: Epicardial Adipose Tissue; EPA: Eicosapentaenoic acids; FFA: free fatty acids; FTO: fat mass and obesity-associated; GISSI: Gruppo Italiano per lo Studio della Sopravvivenza nell'Infarto Miocardico; GST: glutathione S-transferase; GWAS: Genome-wide association studies; HALE: Healthy Ageing: a European longitudinal study; Hcy: homocysteine; HDI: Healthy Diet Indicator; HEI-2010: Healthy Eating Index-2010; HRNMD: Healthy Reference National Mediterranean Diet; hs-CRP: high-sensitive C- Reactive Protein; HSL: hormone-sensitive lipase; IDF: International Diabetes Federation; IL-1: interleukin-1; IL-6: interleukin-6; IMAT: intermuscular adipose tissue; IMOD: Italian Mediterranean Organic Diet; iNOS: inducible nitric oxide synthase; IR: insulin resistance; KANWU: Kopio, Aahhus, Naples, Wollongon and Uppsala; LEP: leptin; LEPR: leptin receptor; MAI: Mediterranean Adequacy Index; MC4R: melanocortin-4 receptor; MCP-1: monocyte-chemotactic protein-1; MD: Mediterranean Diet; MDA: malondialdehyde; MDI: Mediterranean Adequacy Index; MDS: Mediterranean Diet Score; MetS: Metabolic Syndrome; MHMD: moderately hypocaloric Mediterranean Diet; MHO: Metabolically Healthy Obese; MONW: Metabolically Obese Normal Weight; MTHFR: methylenetetrahydrofolate reductase; MUFObes: MUFA in Obesity; MUO: Metabolically Unhealthy Obese; NCEP ATP III: National Cholesterol Education Program's Adult Treatment Panel III report; NO: nitric oxide; NOW: Normal Weight Obese; NTCDs: Non-transmissible Chronic Diseases; OO: olive oil; PAI-1: pro-coagulant substances; PBF: body fat percentage; POMC: proopiomelanocortin; PPAR $\gamma$ : peroxisome proliferatoractivated receptor $\gamma$; PREDIMED: PREvenciòn con DIeta MEDiterrànea; PUFA: polyunsaturated fatty acids; ROS: Reactive Oxygen Species ; RS: renal sinus; SAT: subcutaneous adipose tissue; SFA: saturated fatty acid; SNPs: single nucleotides polymorphisms; SOD: superoxide-dismutase; t-MED: MDS with fish; T2DM: type 2 diabetes mellitus; TAC: Total antioxidant capacity; TCF7L2: transcription factor 7-like 2; TI: Thrombogenic Index; TNF- $\alpha$ : tumor necrosis factor alpha; UAE: urinary albumin excretion; UNESCO: United Nations Educational, Scientific and Cultural Organization; VAT: visceral adipose tissue; VCAM1: vascular cell adhesion-1; VDR: vitamin D receptor; WAT: white adipose tissue. 


\section{ACKNOWLEDGMENTS}

We would like to express gratitude to dr Eleonora Candi for critical reading of the manuscript. This work was supported by grants from Fondazione Roma.

\section{CONFLICTS OF INTEREST}

These authors declare no conflicts of interests.

\section{REFERENCES}

1. Noto D, Cefalù AB, Barbagallo CM, Ganci A, Cavera G, Fayer F, Palesano O, Spina R, Valenti V, Altieri GI, Caldarella R, Giammanco A, Termini R, et al. Baseline metabolic disturbances and the twenty-five years risk of incident cancer in a Mediterranean population. Nutr Metab Cardiovasc Dis. 2016; 26: 1020-5. doi: 10.1016/j. numecd.2016.07.003.

2. D'Alessandro A, De Pergola G, Silvestris F. Mediterranean Diet and cancer risk: an open issue. Int J Food Sci Nutr. 2016; 67: 593-605. doi: 10.1080/096374866.2016.1191444.

3. Xavier Medina F. Mediterranean diet, culture and heritage: challenges for a new conception. Public Health Nutr. 2009; 12: 1618-20. doi: 10.1017/S1368980009990450.

4. Curti MLR, Jacob P, Borges MC, Rogero MM, Ferreira SRG. Studies of Gene Variants Related to Inflammation, Oxidative Stress, Dyslipidemia, and Obesity: Implications for a Nutrigenetic Approach. Journal of Obesity. 2011; 2011: 1-31. doi: 10.1155/2011/497401.

5. Okosun IS, Chandra KMD, Boev A, Boltri JM, Choi ST, Parish DC, Dever GEA. Abdominal adiposity in U.S. adults: prevalence and trends, 1960-2000. Preventive Medicine. 2004; 39: 197-206. doi: 10.1016/j.ypmed.2004.01.023.

6. Li C, Ford ES, McGuire LC, Mokdad AH. Increasing Trends in Waist Circumference and Abdominal Obesity among U.S. Adults*. Obesity. 2007; 15: 216-216. doi: 10.1038/oby.2007.505.

7. Ford ES, Giles WH, Mokdad AH. Increasing prevalence of the metabolic syndrome among u.s. Adults. Diabetes Care. 2004; 27: 2444-9.

8. Ford ES, Li C, Zhao G. Prevalence and correlates of metabolic syndrome based on a harmonious definition among adults in the US*: Metabolic syndrome: A harmonious definition. Journal of Diabetes. 2010; 2: 180 93. doi: 10.1111/j.1753-0407.2010.00078.x.

9. Phillips CM, Tierney AC, Perez-Martinez P, Defoort C, Blaak EE, Gjelstad IMF, Lopez-Miranda J, Kiec-Klimczak M, Malczewska-Malec M, Drevon CA, Hall W, Lovegrove JA, Karlstrom B, et al. Obesity and body fat classification in the metabolic syndrome: Impact on cardiometabolic risk metabotype: Obesity and BF Classification in MetS. Obesity. 2013; 21: E154-61. doi: 10.1002/oby.20263.
10. Zimmet P, Alberti G, Kaufman F, Tajima N, Silink M, Arslanian S, Wong G, Bennett P, Shaw J, Caprio S. The metabolic syndrome in children and adolescents. The Lancet. 2007; 369: 2059-61. doi: 10.1016/ S0140-6736(07)60958-1.

11. Wolin KY, Carson K, Colditz GA. Obesity and Cancer. The Oncologist. 2010; 15: 556-65. doi: 10.1634/ theoncologist.2009-0285.

12. Colditz GA, Atwood KA, Emmons K, Monson RR, Willett WC, Trichopoulos D, Hunter DJ. Harvard report on cancer prevention volume 4: Harvard Cancer Risk Index. Risk Index Working Group, Harvard Center for Cancer Prevention. Cancer Causes Control. 2000; 11: 477-88.

13. Ryan AM, Cushen S, Schellekens H, Bhuachalla EN, Burns L, Kenny U, Power DG. Poor Awareness of Risk Factors for Cancer in Irish Adults: Results of a Large Survey and Review of the Literature. The Oncologist. 2015; 20: 372-8. doi: 10.1634/theoncologist.2014-0453.

14. Kelly T, Yang W, Chen C-S, Reynolds K, He J. Global burden of obesity in 2005 and projections to 2030. International Journal of Obesity. 2008; 32: 1431-7. doi: 10.1038/ijo.2008.102.

15. De Pergola G, Silvestris F. Obesity as a Major Risk Factor for Cancer. Journal of Obesity. 2013; 2013: 1-11. doi: $10.1155 / 2013 / 291546$.

16. Reaven GM. Diet and Syndrome X. Curr Atheroscler Rep. 2000; 2: 503-7.

17. Canale MP, Manca di Villahermosa S, Martino G, Rovella V, Noce A, De Lorenzo A, Di Daniele N. Obesity-Related Metabolic Syndrome: Mechanisms of Sympathetic Overactivity. International Journal of Endocrinology. 2013; 2013: 1-12. doi: 10.1155/2013/865965.

18. Alberti KGMM, Zimmet PZ, WHO Consultation. Definition, diagnosis and classification of diabetes mellitus and its complications. Part 1: diagnosis and classification of diabetes mellitus. Provisional report of a WHO Consultation. Diabetic Medicine. 1998; 15: 539-53. doi: 10.1002/(SICI)1096-9136(199807)15:7<539::AIDDIA668>3.0.CO;2-S.

19. Reaven GM. The Metabolic Syndrome: Requiescat in Pace. Clinical Chemistry. 2005; 51: 931-8. doi: 10.1373/ clinchem.2005.048611.

20. Kahn R, Buse J, Ferrannini E, Stern M, American Diabetes Association, European Association for the Study of Diabetes. The metabolic syndrome: time for a critical appraisal: joint statement from the American Diabetes Association and the European Association for the Study of Diabetes. Diabetes Care. 2005; 28: 2289-304.

21. Scuteri A, Najjar SS, Morrell CH, Lakatta EG, Cardiovascular Health Study. The metabolic syndrome in older individuals: prevalence and prediction of cardiovascular events: the Cardiovascular Health Study. Diabetes Care. 2005; 28: 882-7. 
22. Kondo T, Osugi S, Shimokata K, Honjo H, Morita Y, Yamashita K, Maeda K, Muramatsu T, Shintani S, Matsushita K, Murohara T. Metabolic syndrome and all-cause mortality, cardiac events, and cardiovascular events: a follow-up study in 25,471 young- and middleaged Japanese men. European Journal of Cardiovascular Prevention \& Rehabilitation. 2011; 18: 574-80. doi: $10.1177 / 1741826710389529$.

23. Scuteri A, Tesauro M, Guglini L, Lauro D, Fini M, Di Daniele N. Aortic stiffness and hypotension episodes are associated with impaired cognitive function in older subjects with subjective complaints of memory loss. International Journal of Cardiology. 2013; 169: 371-7. doi: 10.1016/j.ijcard.2013.09.009.

24. Sheen Y-J. Risks of rapid decline renal function in patients with type 2 diabetes. World Journal of Diabetes. 2014; 5: 835. doi: 10.4239/wjd.v5.i6.835.

25. Scheven L, Halbesma N, de Jong PE, de Zeeuw D, Bakker SJL, Gansevoort RT. Predictors of Progression in Albuminuria in the General Population: Results from the PREVEND Cohort. Burdmann EA, editor. PLoS ONE. 2013; 8: e61119. doi: 10.1371/journal.pone.0061119.

26. van der Velde M, Bello AK, Brantsma AH, El Nahas M, Bakker SJL, de Jong PE, Gansevoort RT. Do albuminuria and hs-CRP add to the International Diabetes Federation definition of the metabolic syndrome in predicting outcome? Nephrology Dialysis Transplantation. 2012; 27: 2275-83. doi: 10.1093/ndt/gfr634.

27. Ned RM, Yesupriya A, Imperatore G, Smelser DT, Moonesinghe R, Chang M, Dowling NF. Inflammation gene variants and susceptibility to albuminuria in the U.S. population: analysis in the Third National Health and Nutrition Examination Survey (NHANES III), 1991-1994. BMC Medical Genetics [Internet]. 2010 [cited 2016 Dec 15]; 11. doi: 10.1186/1471-2350-11-155.

28. Levey AS, Atkins R, Coresh J, Cohen EP, Collins AJ, Eckardt K-U, Nahas ME, Jaber BL, Jadoul M, Levin A, Powe NR, Rossert J, Wheeler DC, et al. Chronic kidney disease as a global public health problem: Approaches and initiatives - a position statement from Kidney Disease Improving Global Outcomes. Kidney International. 2007; 72: 247-59. doi: 10.1038/sj.ki.5002343.

29. Lambers Heerspink HJ, Brantsma AH, de Zeeuw D, Bakker SJL, de Jong PE, Gansevoort RT, for the PREVEND Study Group. Albuminuria Assessed From First-Morning-Void Urine Samples Versus 24-Hour Urine Collections as a Predictor of Cardiovascular Morbidity and Mortality. American Journal of Epidemiology. 2008; 168: 897-905. doi: 10.1093/aje/kwn209.

30. Brantsma AH, Bakker SJL, Hillege HL, de Zeeuw D, de Jong PE, Gansevoort RT, PREVEND Study Group. Urinary albumin excretion and its relation with $\mathrm{C}$-reactive protein and the metabolic syndrome in the prediction of type 2 diabetes. Diabetes Care. 2005; 28: 2525-30.
31. Ritz E, Amann K, Koleganova N, Benz K. Prenatal programming - effects on blood pressure and renal function. Nature Reviews Nephrology. 2011; 7: 137-44. doi: 10.1038/nrneph.2011.1.

32. De Lorenzo A, Martinoli R, Vaia F, Di Renzo L. Normal weight obese (NWO) women: An evaluation of a candidate new syndrome. Nutrition, Metabolism and Cardiovascular Diseases. 2006; 16: 513-23. doi: 10.1016/j. numecd.2005.10.010.

33. Karelis AD, St-Pierre DH, Conus F, Rabasa-Lhoret R, Poehlman ET. Metabolic and Body Composition Factors in Subgroups of Obesity: What Do We Know? The Journal of Clinical Endocrinology \& Metabolism. 2004; 89: 2569-75. doi: 10.1210/jc.2004-0165.

34. Karelis AD, Faraj M, Bastard J-P, St-Pierre DH, Brochu M, Prud'homme D, Rabasa-Lhoret R. The Metabolically Healthy but Obese Individual Presents a Favorable Inflammation Profile. The Journal of Clinical Endocrinology \& Metabolism. 2005; 90: 4145-50. doi: 10.1210/jc.2005-0482.

35. Seo MH, Rhee E-J. Metabolic and Cardiovascular Implications of a Metabolically Healthy Obesity Phenotype. Endocrinology and Metabolism. 2014; 29: 427. doi: 10.3803/EnM.2014.29.4.427.

36. Roubenoff R. Sarcopenic obesity: does muscle loss cause fat gain? Lessons from rheumatoid arthritis and osteoarthritis. Ann N Y Acad Sci. 2000; 904: 553-7.

37. De Lorenzo A, Del Gobbo V, Premrov MG, Bigioni M, Galvano F, Di Renzo L. Normal-weight obese syndrome: early inflammation? Am J Clin Nutr. 2007; 85: 40-5.

38. Di Renzo L, Bertoli A, Bigioni M, Del Gobbo V, Premrov MG, Calabrese V, Di Daniele N, De Lorenzo A. Body composition and $-174 \mathrm{G} / \mathrm{C}$ interleukin-6 promoter gene polymorphism: association with progression of insulin resistance in normal weight obese syndrome. Curr Pharm Des. 2008; 14: 2699-706.

39. Di Renzo L, Noce A, De Angelis S, Miani N, Di Daniele N, Tozzo C, De Lorenzo A. Anti-inflammatory effects of combined treatment with acetyl salicylic acid and atorvastatin in haemodialysis patients affected by Normal Weight Obese syndrome. Pharmacological Research. 2008; 57: 93-9. doi: 10.1016/j.phrs.2007.11.005.

40. Di Renzo L, Bigioni M, Bottini FG, Del Gobbo V, Premrov MG, Cianci R, De Lorenzo A. Normal Weight Obese syndrome: role of single nucleotide polymorphism of IL-1 5Ralpha and MTHFR 677C-->T genes in the relationship between body composition and resting metabolic rate. Eur Rev Med Pharmacol Sci. 2006; 10: 235-45.

41. Di Renzo L, Sarlo F, Petramala L, Iacopino L, Monteleone G, Colica C, De Lorenzo A. Association between -308 G/A TNF- $\alpha$ Polymorphism and Appendicular Skeletal Muscle Mass Index as a Marker of Sarcopenia in Normal Weight Obese Syndrome. Disease Markers. 2013; 35: 615-23. doi: $10.1155 / 2013 / 983424$. 
42. Ruderman NB, Schneider SH, Berchtold P. The "metabolically-obese," normal-weight individual. Am J Clin Nutr. 1981; 34: 1617-21.

43. Succurro E, Marini MA, Frontoni S, Hribal ML, Andreozzi F, Lauro R, Perticone F, Sesti G. Insulin Secretion in Metabolically Obese, but Normal Weight, and in Metabolically Healthy but Obese Individuals. Obesity. 2008; 16: 1881-6. doi: 10.1038/oby.2008.308.

44. Esposito K, Giugliano D. The metabolic syndrome and inflammation: association or causation? Nutr Metab Cardiovasc Dis. 2004; 14: 228-32.

45. Lorenzo AD. New obesity classification criteria as a tool for bariatric surgery indication. World Journal of Gastroenterology. 2016; 22: 681. doi: 10.3748/wjg.v22. i2.681.

46. Sims EA. Are there persons who are obese, but metabolically healthy? Metab Clin Exp. 2001; 50: 1499504. doi: 10.1053/meta.2001.27213.

47. Despres J-P. Body Fat Distribution and Risk of Cardiovascular Disease: An Update. Circulation. 2012; 126: 1301-13. doi: 10.1161/CIRCULATIONAHA.111.067264.

48. Mohamed EI, Maiolo C, Iacopino L, Pepe M, Daniele N, Lorenzo A. The Impact of Body-Weight Components on Forced Spirometry in Healthy Italians. Lung. 2002; 180: 149-59. doi: 10.1007/s004080000089.

49. Kim $\mathrm{CH}$, Younossi ZM. Nonalcoholic fatty liver disease: a manifestation of the metabolic syndrome. Cleve Clin J Med. 2008; 75: 721-8.

50. Evans WJ. Skeletal muscle loss: cachexia, sarcopenia, and inactivity. American Journal of Clinical Nutrition. 2010; 91: 1123S-1127S. doi: 10.3945/ajen.2010.28608A.

51. Schrager MA, Metter EJ, Simonsick E, Ble A, Bandinelli S, Lauretani F, Ferrucci L. Sarcopenic obesity and inflammation in the InCHIANTI study. Journal of Applied Physiology. 2006; 102: 919-25. doi: 10.1152/ japplphysiol.00627.2006.

52. Wang Z, Nakayama T. Inflammation, a Link between Obesity and Cardiovascular Disease. Mediators of Inflammation. 2010; 2010: 1-17. doi: 10.1155/2010/535918.

53. Drubach LA, Palmer EL, Connolly LP, Baker A, Zurakowski D, Cypess AM. Pediatric Brown Adipose Tissue: Detection, Epidemiology, and Differences from Adults. The Journal of Pediatrics. 2011; 159: 939-44. doi: 10.1016/j.jpeds.2011.06.028.

54. Virtanen KA, Lidell ME, Orava J, Heglind M, Westergren R, Niemi T, Taittonen M, Laine J, Savisto N-J, Enerbäck S, Nuutila P. Functional Brown Adipose Tissue in Healthy Adults. New England Journal of Medicine. 2009; 360: 1518-25. doi: 10.1056/NEJMoa0808949.

55. Nedergaard J, Bengtsson T, Cannon B. Unexpected evidence for active brown adipose tissue in adult humans. AJP: Endocrinology and Metabolism. 2007; 293: E444-52. doi: 10.1152/ajpendo.00691.2006.
56. Villarroya J, Cereijo R, Villarroya F. An endocrine role for brown adipose tissue? AJP: Endocrinology and Metabolism. 2013; 305: E567-72. doi: 10.1152/ajpendo.00250.2013.

57. Spalding KL, Arner E, Westermark PO, Bernard S, Buchholz BA, Bergmann O, Blomqvist L, Hoffstedt J, Näslund E, Britton T, Concha H, Hassan M, Rydén M, et al. Dynamics of fat cell turnover in humans. Nature. 2008; 453: 783-7. doi: 10.1038/nature06902.

58. Taveras EM, Rifas-Shiman SL, Belfort MB, Kleinman KP, Oken E, Gillman MW. Weight Status in the First 6 Months of Life and Obesity at 3 Years of Age. PEDIATRICS. 2009; 123: 1177-83. doi: 10.1542/peds.2008-1149.

59. Rolland-Cachera MF, Deheeger M, Bellisle F, Sempé M, Guilloud-Bataille M, Patois E. Adiposity rebound in children: a simple indicator for predicting obesity. Am J Clin Nutr. 1984; 39: 129-35.

60. Klein S, Allison DB, Heymsfield SB, Kelley DE, Leibel RL, Nonas C, Kahn R, Association for Weight Management and Obesity Prevention, NAASO, Obesity Society, American Society for Nutrition, American Diabetes Association. Waist circumference and cardiometabolic risk: a consensus statement from shaping America's health: Association for Weight Management and Obesity Prevention; NAASO, the Obesity Society; the American Society for Nutrition; and the American Diabetes Association. Diabetes Care. 2007; 30: 1647-52. doi: 10.2337/dc07-9921.

61. Alexopoulos N, Katritsis D, Raggi P. Visceral adipose tissue as a source of inflammation and promoter of atherosclerosis. Atherosclerosis. 2014; 233: 104-12. doi: 10.1016/j. atherosclerosis.2013.12.023.

62. van Harmelen V, Skurk T, Röhrig K, Lee Y-M, Halbleib M, Aprath-Husmann I, Hauner H. Effect of BMI and age on adipose tissue cellularity and differentiation capacity in women. International Journal of Obesity. 2003; 27: 889-95. doi: 10.1038/sj.ijo.0802314.

63. Hausman DB, DiGirolamo M, Bartness TJ, Hausman GJ, Martin RJ. The biology of white adipocyte proliferation. Obes Rev. 2001; 2: 239-54.

64. Bays HE, González-Campoy JM, Bray GA, Kitabchi AE, Bergman DA, Schorr AB, Rodbard HW, Henry RR. Pathogenic potential of adipose tissue and metabolic consequences of adipocyte hypertrophy and increased visceral adiposity. Expert Review of Cardiovascular Therapy. 2008; 6: 343-68. doi: 10.1586/14779072.6.3.343.

65. Bays H, Blonde L, Rosenson R. Adiposopathy: how do diet, exercise and weight loss drug therapies improve metabolic disease in overweight patients? Expert Review of Cardiovascular Therapy. 2006; 4: 871-95. doi: 10.1586/14779072.4.6.871.

66. Bays HE. Adiposopathy. Journal of the American College of Cardiology. 2011; 57: 2461-73. doi: 10.1016/j. jacc.2011.02.038. 
67. Liu L, Mei M, Yang S, Li Q. Roles of Chronic LowGrade Inflammation in the Development of Ectopic Fat Deposition. Mediators of Inflammation. 2014; 2014: 1-7. doi: $10.1155 / 2014 / 418185$.

68. Lumeng CN, Saltiel AR. Inflammatory links between obesity and metabolic disease. Journal of Clinical Investigation. 2011; 121: 2111-7. doi: 10.1172/JCI57132.

69. Blüher M. Adipose tissue dysfunction contributes to obesity related metabolic diseases. Best Pract Res Clin Endocrinol Metab. 2013; 27: 163-77. doi: 10.1016/j.beem.2013.02.005.

70. Castoldi A, Naffah de Souza C, Câmara NOS, MoraesVieira PM. The Macrophage Switch in Obesity Development. Frontiers in Immunology [Internet]. 2016 [cited 2016 Dec 15]; 6. doi: 10.3389/fimmu.2015.00637.

71. Brookheart RT, Michel CI, Schaffer JE. As a Matter of Fat. Cell Metabolism. 2009; 10: 9-12. doi: 10.1016/j. cmet.2009.03.011.

72. DeFronzo RA. Dysfunctional fat cells, lipotoxicity and type 2 diabetes. Int J Clin Pract Suppl. 2004; : 9-21.

73. Gao M, Ma Y, Liu D. High-Fat Diet-Induced Adiposity, Adipose Inflammation, Hepatic Steatosis and Hyperinsulinemia in Outbred CD-1 Mice. Stadler K, editor. PLOS ONE. 2015; 10: e0119784. doi: 10.1371/journal. pone.0119784.

74. Nadler ST, Attie AD. Please pass the chips: genomic insights into obesity and diabetes. J Nutr. 2001; 131: 2078-81.

75. Foster MC, Hwang S-J, Porter SA, Massaro JM, Hoffmann U, Fox CS. Fatty Kidney, Hypertension, and Chronic Kidney Disease: The Framingham Heart Study. Hypertension. 2011; 58: 784-90. doi: 10.1161/ HYPERTENSIONAHA.111.175315.

76. Chughtai HL, Morgan TM, Rocco M, Stacey B, Brinkley TE, Ding J, Nicklas B, Hamilton C, Hundley WG. Renal Sinus Fat and Poor Blood Pressure Control in MiddleAged and Elderly Individuals at Risk for Cardiovascular Events. Hypertension. 2010; 56: 901-6. doi: 10.1161/ HYPERTENSIONAHA.110.157370.

77. Tesauro M, Mascali A, Franzese O, Cipriani S, Cardillo C, Di Daniele N. Chronic Kidney Disease, Obesity, and Hypertension: The Role of Leptin and Adiponectin. International Journal of Hypertension. 2012; 2012: 1-7. doi: $10.1155 / 2012 / 943605$.

78. Bertaso AG, Bertol D, Duncan BB, Foppa M. Epicardial Fat: Definition, Measurements and Systematic Review of Main Outcomes. Arquivos Brasileiros de Cardiologia [Internet]. 2013 [cited 2016 Dec 15]; . doi: 10.5935/ abc. 20130138 .

79. Talman AH, Psaltis PJ, Cameron JD, Meredith IT, Seneviratne SK, Wong DTL. Epicardial adipose tissue: far more than a fat depot. Cardiovasc Diagn Ther. 2014; 4: 416-29. doi: 10.3978/j.issn.2223-3652.2014.11.05.

80. Iacobellis G, Willens HJ. Echocardiographic epicardial fat: a review of research and clinical applications. J Am Soc
Echocardiogr. 2009; 22: 1311-1319-1418. doi: 10.1016/j. echo.2009.10.013.

81. Song DK, Hong YS, Lee H, Oh J-Y, Sung Y-A, Kim Y. Increased Epicardial Adipose Tissue Thickness in Type 2 Diabetes Mellitus and Obesity. Diabetes \& Metabolism Journal. 2015; 39: 405. doi: 10.4093/dmj.2015.39.5.405.

82. Iacobellis G, Malavazos AE, Corsi MM. Epicardial fat: From the biomolecular aspects to the clinical practice. The International Journal of Biochemistry \& Cell Biology. 2011; 43: 1651-4. doi: 10.1016/j.biocel.2011.09.006.

83. Goodpaster BH, Thaete FL, Kelley DE. Thigh adipose tissue distribution is associated with insulin resistance in obesity and in type 2 diabetes mellitus. Am J Clin Nutr. 2000; 71: 885-92.

84. Addison O, Marcus RL, LaStayo PC, Ryan AS. Intermuscular Fat: A Review of the Consequences and Causes. International Journal of Endocrinology. 2014; 2014: 1-11. doi: 10.1155/2014/309570.

85. Sales NMR, Pelegrini PB, Goersch MC. Nutrigenomics: Definitions and Advances of This New Science. Journal of Nutrition and Metabolism. 2014; 2014: 1-6. doi: $10.1155 / 2014 / 202759$.

86. Brennan RO, Mulligan WC. Nutrigenetics: new concepts for relieving hypoglycemia. New York; Philadelphia: M. Evans ; Distributed by Lippincott; 1975.

87. Phillips C, Lopez-Miranda J, Perez-Jimenez F, McManus $\mathrm{R}$, Roche HM. Genetic and nutrient determinants of the metabolic syndrome: Current Opinion in Cardiology. 2006; 21: 185-93. doi: 10.1097/01.hco.0000221579.25878.11.

88. Phillips CM, Tierney AC, Roche HM. Gene-Nutrient Interactions in the Metabolic Syndrome. Journal of Nutrigenetics and Nutrigenomics. 2008; 1: 136-51. doi: 10.1159/000112461.

89. Roche HM, Phillips C, Gibney MJ. The metabolic syndrome: the crossroads of diet and genetics. Proc Nutr Soc. 2005; 64: 371-7.

90. Phillips C. Nutrigenetics and Metabolic Disease: Current Status and Implications for Personalised Nutrition. Nutrients. 2013; 5: 32-57. doi: 10.3390/nu5010032.

91. Neel JV. Diabetes mellitus: a "thrifty" genotype rendered detrimental by "progress"? Am J Hum Genet. 1962; 14: $353-62$.

92. Andreasen $\mathrm{CH}$, Andersen G. Gene-environment interactions and obesity - Further aspects of genomewide association studies. Nutrition. 2009; 25: 998-1003. doi: 10.1016/j.nut.2009.06.001.

93. Horikawa Y, Oda N, Cox NJ, Li X, Orho-Melander M, Hara M, Hinokio Y, Lindner TH, Mashima H, Schwarz PEH, del Bosque-Plata L, Horikawa Y, Oda Y, et al. Genetic variation in the gene encoding calpain-10 is associated with type 2 diabetes mellitus. Nature Genetics. 2000; 26: 163-75. doi: 10.1038/79876.

94. Haupt A, Thamer C, Staiger H, Tschritter O, Kirchhoff K, Machicao F, Häring H-U, Stefan N, Fritsche A. 
Variation in the FTO Gene Influences Food Intake but not Energy Expenditure. Experimental and Clinical Endocrinology \&amp; Diabetes. 2009; 117: 194-7. doi: 10.1055/s-0028-1087176.

95. Povel CM, Boer JMA, Reiling E, Feskens EJM. Genetic variants and the metabolic syndrome: a systematic review: Genetics of metabolic syndrome. Obesity Reviews. 2011; 12: 952-67. doi: 10.1111/j.1467-789X.2011.00907.x.

96. Garcia-Rios A, Perez-Martinez P, Delgado-Lista J, Phillips CM, Gjelstad IMF, Wright JW, Karlstrom B, Kiec-Wilk B, van Hees AMJ, Helal O, Polus A, Defoort C, Riserus U, et al. A Period 2 Genetic Variant Interacts with Plasma SFA to Modify Plasma Lipid Concentrations in Adults with Metabolic Syndrome. Journal of Nutrition. 2012; 142: 1213-8. doi: 10.3945/jn.111.156968.

97. Deeb SS, Fajas L, Nemoto M, Pihlajamäki J, Mykkänen L, Kuusisto J, Laakso M, Fujimoto W, Auwerx J. A Pro12Ala substitution in PPARgamma2 associated with decreased receptor activity, lower body mass index and improved insulin sensitivity. Nat Genet. 1998; 20: 284-7. doi: 10.1038/3099.

98. Florez JC, Hirschhorn J, Altshuler D. The inherited basis of diabetes mellitus: implications for the genetic analysis of complex traits. Annu Rev Genomics Hum Genet. 2003; 4: 257-91. doi: 10.1146/annurev.genom.4.070802.110436.

99. Vaccaro O, Lapice E, Monticelli A, Giacchetti M, Castaldo I, Galasso R, Pinelli M, Donnarumma G, Rivellese AA, Cocozza S, Riccardi G. Pro12Ala polymorphism of the PPARgamma2 locus modulates the relationship between energy intake and body weight in type 2 diabetic patients. Diabetes Care. 2007; 30: 1156-61. doi: 10.2337/dc06-1153.

100. Phillips CM, Goumidi L, Bertrais S, Field MR, Cupples LA, Ordovas JM, Defoort C, Lovegrove JA, Drevon CA, Gibney MJ, Blaak EE, Kiec-Wilk B, Karlstrom B, et al. Gene-nutrient interactions with dietary fat modulate the association between genetic variation of the ACSL1 gene and metabolic syndrome. J Lipid Res. 2010; 51: 1793-800. doi: 10.1194/jlr.M003046.

101. Phillips CM, Goumidi L, Bertrais S, Field MR, Ordovas JM, Cupples LA, Defoort C, Lovegrove JA, Drevon CA, Blaak EE, Gibney MJ, Kiec-Wilk B, Karlstrom B, et al. Leptin Receptor Polymorphisms Interact with Polyunsaturated Fatty Acids to Augment Risk of Insulin Resistance and Metabolic Syndrome in Adults. Journal of Nutrition. 2010; 140: 238-44. doi: 10.3945/jn.109.115329.

102. Daimiel L, Vargas T, Ramírez de Molina A. Nutritional genomics for the characterization of the effect of bioactive molecules in lipid metabolism and related pathways: General. ELECTROPHORESIS. 2012; 33: 2266-89. doi: 10.1002/elps.201200084.

103. Rana S, Kumar S, Rathore N, Padwad Y, Bhushan S. Nutrigenomics and its Impact on Life Style Associated Metabolic Diseases. Current Genomics. 2016; 17: 261-78. doi: $10.2174 / 1389202917666160202220422$.
104. Arkadianos I, Valdes AM, Marinos E, Florou A, Gill $\mathrm{RD}$, Grimaldi KA. Improved weight management using genetic information to personalize a calorie controlled diet. Nutrition Journal [Internet]. 2007 [cited 2016 Dec 15]; 6. doi: 10.1186/1475-2891-6-29.

105. Di Renzo L, Rizzo M, Iacopino L, Sarlo F, Domino E, Jacoangeli F, Colica C, Sergi D, De Lorenzo A. Body composition phenotype: Italian Mediterranean Diet and C677T MTHFR gene polymorphism interaction. Eur Rev Med Pharmacol Sci. 2013; 17: 2555-65.

106. Kirke PN. Impact of the MTHFR C677T polymorphism on risk of neural tube defects: case-control study. BMJ. 2004; 328: 1535-6. doi: 10.1136/bmj.38036.646030.EE.

107. Elhawary NA, Hewedi D, Arab A, Teama S, Shaibah H, Tayeb MT, Bogari N. The MTHFR 677T Allele May Influence the Severity and Biochemical Risk Factors of Alzheimer's Disease in an Egyptian Population. Disease Markers. 2013; 35: 439-46. doi: 10.1155/2013/524106.

108. McLean RR, Karasik D, Selhub J, Tucker KL, Ordovas JM, Russo GT, Cupples LA, Jacques PF, Kiel DP. Association of a Common Polymorphism in the Methylenetetrahydrofolate Reductase (MTHFR) Gene With Bone Phenotypes Depends on Plasma Folate Status. Journal of Bone and Mineral Research. 2003; 19: 410-8. doi: 10.1359/JBMR.0301261.

109. Homocysteine Lowering Trialists' Collaboration. Dosedependent effects of folic acid on blood concentrations of homocysteine: a meta-analysis of the randomized trials. Am J Clin Nutr. 2005; 82: 806-12.

110. Pastore A. Effects of Folic Acid Before and After Vitamin B12 on Plasma Homocysteine Concentrations in Hemodialysis Patients with Known MTHFR Genotypes. Clinical Chemistry. 2006; 52: 145-8. doi: 10.1373/ clinchem.2005.056119.

111. Alberti A, Fruttini D, Fidanza F. The Mediterranean Adequacy Index: Further confirming results of validity. Nutrition, Metabolism and Cardiovascular Diseases. 2009; 19: 61-6. doi: 10.1016/j.numecd.2007.11.008.

112. Alberti-Fidanza A, Fidanza F, Chiuchiù MP, Verducci G, Fruttini D. Dietary studies on two rural italian population groups of the Seven Countries Study. 3. Trend Of food and nutrient intake from 1960 to 1991. Eur J Clin Nutr. 1999; 53: 854-60.

113. Fidanza F, Alberti A, Lanti M, Menotti A. Mediterranean Adequacy Index: correlation with 25-year mortality from coronary heart disease in the Seven Countries Study. Nutr Metab Cardiovasc Dis. 2004; 14: 254-8.

114. Menotti A, Alberti-Fidanza A, Fidanza F. The association of the Mediterranean Adequacy Index with fatal coronary events in an Italian middle-aged male population followed for 40 years. Nutrition, Metabolism and Cardiovascular Diseases. 2012; 22: 369-75. doi: 10.1016/j. numecd.2010.08.002.

115. De Lorenzo A, Petroni ML, De Luca PP, Andreoli A, Morini P, Iacopino L, Innocente I, Perriello G. Use of quality 
control indices in moderately hypocaloric Mediterranean diet for treatment of obesity. Diabetes Nutr Metab. 2001; 14: $181-8$.

116. Bilenko N, Fraser D, Vardi H, Shai I, Shahar D. Mediterranean diet and cardiovascular diseases in an Israeli population. Preventive Medicine. 2005; 40: 299-305. doi: 10.1016/j.ypmed.2004.06.004.

117. Trichopoulou A, Kouris-Blazos A, Wahlqvist ML, Gnardellis C, Lagiou P, Polychronopoulos E, Vassilakou T, Lipworth L, Trichopoulos D. Diet and overall survival in elderly people. BMJ. 1995; 311: 1457-60.

118. Tektonidis TG, Åkesson A, Gigante B, Wolk A, Larsson SC. Adherence to a Mediterranean diet is associated with reduced risk of heart failure in men. Eur J Heart Fail. 2016; 18: 253-9. doi: 10.1002/ejhf.481.

119. A. De Lorenzo, Fidanza, F. Dieta mediterranea Italiana di Riferimento, la Dieta di Nicotera, 1960. MSI-Edizioni Mediche Scientifiche Internazionali-Roma. Sezione di Alimentazione e Nutrizione Umana, Dipartimento di Neuroscienze, Università di Roma Tor Vergata; 2003.

120. Harmon BE, Boushey CJ, Shvetsov YB, Ettienne R, Reedy J, Wilkens LR, Le Marchand L, Henderson BE, Kolonel LN. Associations of key diet-quality indexes with mortality in the Multiethnic Cohort: the Dietary Patterns Methods Project. American Journal of Clinical Nutrition. 2015; 101: 587-97. doi: 10.3945/ajen.114.090688.

121. Salas-Salvadó J, Fernández-Ballart J, Ros E, MartínezGonzález M-A, Fitó M, Estruch R, Corella D, Fiol M, Gómez-Gracia E, Arós F, Flores G, Lapetra J, LamuelaRaventós R, et al. Effect of a Mediterranean diet supplemented with nuts on metabolic syndrome status: one-year results of the PREDIMED randomized trial. Arch Intern Med. 2008; 168: 2449-58. doi: 10.1001/ archinte.168.22.2449.

122. Estruch R, Ros E, Salas-Salvadó J, Covas M-I, Corella D, Arós F, Gómez-Gracia E, Ruiz-Gutiérrez V, Fiol M, Lapetra J, Lamuela-Raventos RM, Serra-Majem L, Pintó $\mathrm{X}$, et al. Primary Prevention of Cardiovascular Disease with a Mediterranean Diet. New England Journal of Medicine. 2013; 368: 1279-90. doi: 10.1056/NEJMoa1200303.

123. Babio N, Toledo E, Estruch R, Ros E, Martinez-Gonzalez MA, Castaner O, Bullo M, Corella D, Aros F, GomezGracia E, Ruiz-Gutierrez V, Fiol M, Lapetra J, et al. Mediterranean diets and metabolic syndrome status in the PREDIMED randomized trial. Canadian Medical Association Journal. 2014; 186: E649-57. doi: 10.1503/ cmaj.140764.

124. Grosso G, Marventano S, Yang J, Micek A, Pajak A, Scalfi L, Galvano F, Kales SN. A Comprehensive Meta-analysis on Evidence of Mediterranean Diet and Cardiovascular Disease: Are Individual Components Equal? Critical Reviews in Food Science and Nutrition. 2015. doi: 10.1080/10408398.2015.1107021.

125. Pitsavos C, Panagiotakos DB, Tzima N, Chrysohoou C, Economou M, Zampelas A, Stefanadis C. Adherence to the Mediterranean diet is associated with total antioxidant capacity in healthy adults: the ATTICA study. Am J Clin Nutr. 2005; 82: 694-9.

126. Sofi F, Cesari F, Abbate R, Gensini GF, Casini A. Adherence to Mediterranean diet and health status: meta-analysis. BMJ. 2008; 337: a1344-a1344. doi: 10.1136/bmj.a1344.

127. Chrysohoou C, Panagiotakos DB, Pitsavos C, Das UN, Stefanadis C. Adherence to the Mediterranean diet attenuates inflammation and coagulation process in healthy adults. Journal of the American College of Cardiology. 2004; 44: 152-8. doi: 10.1016/j.jacc.2004.03.039.

128. Psaltopoulou T, Naska A, Orfanos P, Trichopoulos D, Mountokalakis T, Trichopoulou A. Olive oil, the Mediterranean diet, and arterial blood pressure: the Greek European Prospective Investigation into Cancer and Nutrition (EPIC) study. Am J Clin Nutr. 2004; 80: 1012-8.

129. Andreoli A, Lauro S, Di Daniele N, Sorge R, Celi M, Volpe SL. Effect of a moderately hypoenergetic Mediterranean diet and exercise program on body cell mass and cardiovascular risk factors in obese women. European Journal of Clinical Nutrition. 2008; 62: 892-7. doi: 10.1038/sj.ejcn.1602800.

130. Andreoli A, Melchiorri G, Brozzi M, Di Marco A, Volpe SL, Garofano P, Di Daniele N, De Lorenzo A. Effect of different sports on body cell mass in highly trained athletes. Acta Diabetologica. 2003; 40: s122-5. doi: 10.1007/ s00592-003-0043-9.

131. De Lorenzo A, Noce A, Bigioni M, Calabrese V, Della Rocca DG, Di Daniele N, Tozzo C, Di Renzo L. The effects of Italian Mediterranean organic diet (IMOD) on health status. Curr Pharm Des. 2010; 16: 814-24.

132. Di Daniele N, Di Renzo L, Noce A, Iacopino L, Ferraro PM, Rizzo M, Sarlo F, Domino E, De Lorenzo A. Effects of Italian Mediterranean organic diet vs. low-protein diet in nephropathic patients according to MTHFR genotypes. Journal of Nephrology. 2014; 27: 529-36. doi: 10.1007/ s40620-014-0067-y.

133. Noce A, Vidiri MF, Marrone G, Moriconi E, Bocedi A, Capria A, Rovella V, Ricci G, De Lorenzo A, Di Daniele $\mathrm{N}$. Is low-protein diet a possible risk factor of malnutrition in chronic kidney disease patients? Cell Death Discovery. 2016; 2: 16026. doi: 10.1038/cddiscovery.2016.26.

134. Di Daniele N, Petramala L, Di Renzo L, Sarlo F, Della Rocca DG, Rizzo M, Fondacaro V, Iacopino L, Pepine CJ, De Lorenzo A. Body composition changes and cardiometabolic benefits of a balanced Italian Mediterranean Diet in obese patients with metabolic syndrome. Acta Diabetologica. 2013; 50: 409-16. doi: 10.1007/s00592-012-0445-7.

135. De Lorenzo A, Alberti A, Andreoli A, Iacopino L, Serranò P, Perriello G. Food habits in a southern Italian town (Nicotera) in 1960 and 1996: still a reference Italian Mediterranean diet? Diabetes Nutr Metab. 2001; 14: 121-5.

136. Menotti A, Kromhout D, Blackburn H, Fidanza F, Buzina $\mathrm{R}$, Nissinen A. Food intake patterns and 25-year mortality 
from coronary heart disease: cross-cultural correlations in the Seven Countries Study. The Seven Countries Study Research Group. Eur J Epidemiol. 1999; 15: 507-15.

137. Tierney AC, McMonagle J, Shaw DI, Gulseth HL, Helal O, Saris WHM, Paniagua JA, Gołąbek-Leszczyñska I, Defoort C, Williams CM, Karsltröm B, Vessby B, DembinskaKiec A, et al. Effects of dietary fat modification on insulin sensitivity and on other risk factors of the metabolic syndrome-LIPGENE: a European randomized dietary intervention study. International Journal of Obesity. 2011; 35: 800-9. doi: 10.1038/ijo.2010.209.

138. Due A, Larsen TM, Mu H, Hermansen K, Stender S, Astrup A. Comparison of 3 ad libitum diets for weight-loss maintenance, risk of cardiovascular disease, and diabetes: a 6-mo randomized, controlled trial. Am J Clin Nutr. 2008; 88: $1232-41$.

139. Due A, Larsen TM, Hermansen K, Stender S, Holst JJ, Toubro S, Martinussen T, Astrup A. Comparison of the effects on insulin resistance and glucose tolerance of 6-mo high-monounsaturated-fat, low-fat, and control diets. Am J Clin Nutr. 2008; 87: 855-62.

140. Vessby B, Uusitupa M, Hermansen K, Riccardi G, Rivellese AA, Tapsell LC, Nälsén C, Berglund L, Louheranta A, Rasmussen BM, Calvert GD, Maffetone A, Pedersen E, et al. Substituting dietary saturated for monounsaturated fat impairs insulin sensitivity in healthy men and women: The KANWU Study. Diabetologia. 2001; 44: 312-9.

141. Maehre H, Jensen I-J, Elvevoll E, Eilertsen K-E. $\omega-3$ Fatty Acids and Cardiovascular Diseases: Effects, Mechanisms and Dietary Relevance. International Journal of Molecular Sciences. 2015; 16: 22636-61. doi: 10.3390/ ijms160922636.

142. Li G-R, Sun H-Y, Zhang X-H, Cheng L-C, Chiu S-W, Tse H-F, Lau C-P. Omega-3 polyunsaturated fatty acids inhibit transient outward and ultra-rapid delayed rectifier $\mathrm{K}+$ currents and $\mathrm{Na}+$ current in human atrial myocytes. Cardiovascular Research. 2008; 81: 286-93. doi: 10.1093/ cvr/cvn322.

143. Xiao Y-F, Sigg DC, Leaf A. The Antiarrhythmic Effect of n-3 Polyunsaturated Fatty Acids: Modulation of Cardiac Ion Channels as a Potential Mechanism. Journal of Membrane Biology. 2005; 206: 141-54. doi: 10.1007/ s00232-005-0786-z.

144. Marventano S, Kolacz P, Castellano S, Galvano F, Buscemi S, Mistretta A, Grosso G. A review of recent evidence in human studies of n-3 and n-6 PUFA intake on cardiovascular disease, cancer, and depressive disorders: does the ratio really matter? International Journal of Food Sciences and Nutrition. 2015; 66: 611-22. doi: 10.3109/09637486.2015.1077790.

145. Angelico F, Loffredo L, Pignatelli P, Augelletti T, Carnevale R, Pacella A, Albanese F, Mancini I, Di Santo S, Del Ben M, Violi F. Weight loss is associated with improved endothelial dysfunction via NOX2-generated oxidative stress down-regulation in patients with the metabolic syndrome. Internal and Emergency Medicine. 2012; 7: 219-27. doi: 10.1007/s11739-011-0591-x.

146. de Beer D, Joubert E, Marais J, Manley M. Unravelling the Total Antioxidant Capacity of Pinotage Wines: Contribution of Phenolic Compounds. Journal of Agricultural and Food Chemistry. 2006; 54: 2897-905. doi: 10.1021/jf052766u.

147. Di Renzo L, Carraro A, Valente R, Iacopino L, Colica C, De Lorenzo A. Intake of Red Wine in Different Meals Modulates Oxidized LDL Level, Oxidative and Inflammatory Gene Expression in Healthy People: A Randomized Crossover Trial. Oxidative Medicine and Cellular Longevity. 2014; 2014: 1-9. doi: 10.1155/2014/681318.

148. Dong Z. Molecular mechanism of the chemopreventive effect of resveratrol. Mutat Res. 2003; 523-524: 145-50.

149. Fischer-Posovszky P, Kukulus V, Tews D, Unterkircher T, Debatin K-M, Fulda S, Wabitsch M. Resveratrol regulates human adipocyte number and function in a Sirt1-dependent manner. American Journal of Clinical Nutrition. 2010; 92: 5-15. doi: 10.3945/ajen.2009.28435.

150. Tresserra-Rimbau A, Medina-Remón A, Lamuela-Raventós RM, Bulló M, Salas-Salvadó J, Corella D, Fitó M, Gea A, Gómez-Gracia E, Lapetra J, Arós F, Fiol M, Ros E, et al. Moderate red wine consumption is associated with a lower prevalence of the metabolic syndrome in the PREDIMED population. British Journal of Nutrition. 2015; 113: S12130. doi: 10.1017/S0007114514003262.

151. Feng D, Ling W-H, Duan R-D. Lycopene suppresses LPS-induced NO and IL-6 production by inhibiting the activation of ERK, p38MAPK, and NF- $\mathrm{kB}$ in macrophages. Inflammation Research. 2010; 59: 115-21. doi: 10.1007/ s00011-009-0077-8.

152. Ghavipour M, Saedisomeolia A, Djalali M, Sotoudeh G, Eshraghyan MR, Moghadam AM, Wood LG. Tomato juice consumption reduces systemic inflammation in overweight and obese females. British Journal of Nutrition. 2013; 109: 2031-5. doi: 10.1017/S0007114512004278.

153. McEneny J, Wade L, Young IS, Masson L, Duthie G, McGinty A, McMaster C, Thies F. Lycopene intervention reduces inflammation and improves HDL functionality in moderately overweight middle-aged individuals. The Journal of Nutritional Biochemistry. 2013; 24: 163-8. doi: 10.1016/j.jnutbio.2012.03.015.

154. Li Y-F, Chang Y-Y, Huang H-C, Wu Y-C, Yang M-D, Chao $\mathrm{P}-\mathrm{M}$. Tomato juice supplementation in young women reduces inflammatory adipokine levels independently of body fat reduction. Nutrition. 2015; 31: 691-6. doi: 10.1016/j.nut.2014.11.008.

155. Fuentes E, Forero-Doria O, Carrasco G, Maricán A, Santos L, Alarcón M, Palomo I. Effect of Tomato Industrial Processing on Phenolic Profile and Antiplatelet Activity. Molecules. 2013; 18: 11526-36. doi: 10.3390/ molecules 180911526. 
156. Moreno-Luna R, Muñoz-Hernandez R, Miranda ML, Costa AF, Jimenez-Jimenez L, Vallejo-Vaz AJ, Muriana FJG, Villar J, Stiefel P. Olive Oil Polyphenols Decrease Blood Pressure and Improve Endothelial Function in Young Women with Mild Hypertension. American Journal of Hypertension [Internet]. 2012 [cited 2016 Dec 15]; . doi: 10.1038/ajh.2012.128.

157. Christoph L, Hoffmann G, Christoph M. Effects of Olive Oil on Markers of Inflammation and Endothelial Function-A Systematic Review and Meta-Analysis. Nutrients. 2015; 7: 7651-75. doi: 10.3390/nu7095356.

158. Zern TL, Fernandez ML. Cardioprotective effects of dietary polyphenols. J Nutr. 2005; 135: 2291-4.

159. Sánchez-Fidalgo S, Sánchez de Ibargüen L, Cárdeno A, Alarcón de la Lastra C. Influence of extra virgin olive oil diet enriched with hydroxytyrosol in a chronic DSS colitis model. European Journal of Nutrition. 2012; 51: 497-506. doi: 10.1007/s00394-011-0235-y.

160. Ruano J, Lopez-Miranda J, Fuentes F, Moreno JA, Bellido C, Perez-Martinez P, Lozano A, Gómez P, Jiménez Y, Pérez Jiménez F. Phenolic Content of Virgin Olive Oil Improves Ischemic Reactive Hyperemia in Hypercholesterolemic Patients. Journal of the American College of Cardiology. 2005; 46: 1864-8. doi: 10.1016/j.jacc.2005.06.078.

161. Ramírez-Anaya J del P, Samaniego-Sánchez C, CastañedaSaucedo MC, Villalón-Mir M, de la Serrana HL-G. Phenols and the antioxidant capacity of Mediterranean vegetables prepared with extra virgin olive oil using different domestic cooking techniques. Food Chemistry. 2015; 188: 430-8. doi: 10.1016/j.foodchem.2015.04.124.

162. Martínez-González MA, Sánchez-Villegas A. The emerging role of Mediterranean diets in cardiovascular epidemiology: monounsaturated fats, olive oil, red wine or the whole pattern? Eur J Epidemiol. 2004; 19: 9-13.

163. Fitó M. Effect of a Traditional Mediterranean Diet on Lipoprotein Oxidation: A Randomized Controlled Trial. Archives of Internal Medicine. 2007; 167: 1195. doi: 10.1001/archinte.167.11.1195.

164. Babio N, Bulló M, Salas-Salvadó J. Mediterranean diet and metabolic syndrome: the evidence. Public Health Nutrition. 2009; 12: 1607. doi: 10.1017/S1368980009990449.

165. Cho SS, Qi L, Fahey GC, Klurfeld DM. Consumption of cereal fiber, mixtures of whole grains and bran, and whole grains and risk reduction in type 2 diabetes, obesity, and cardiovascular disease. American Journal of Clinical Nutrition. 2013; 98: 594-619. doi: 10.3945/ ajen.113.067629.

166. Cuenca-García M, Artero EG, Sui X, Lee D, Hebert JR, Blair SN. Dietary indices, cardiovascular risk factors and mortality in middle-aged adults: findings from the Aerobics Center Longitudinal Study. Annals of Epidemiology. 2014; 24: 297-303.e2. doi: 10.1016/j.annepidem.2014.01.007.

167. Grosso G, Marventano S, Galvano F, Pajak A, Mistretta A. Factors associated with metabolic syndrome in a mediterranean population: role of caffeinated beverages. J Epidemiol. 2014; 24: 327-33.

168. Shaughnessy KS, Boswall IA, Scanlan AP, GottschallPass KT, Sweeney MI. Diets containing blueberry extract lower blood pressure in spontaneously hypertensive strokeprone rats. Nutr Res. 2009; 29: 130-8. doi: 10.1016/j. nutres.2009.01.001.

169. Kalea AZ, Clark K, Schuschke DA, Klimis-Zacas DJ. Vascular reactivity is affected by dietary consumption of wild blueberries in the Sprague-Dawley rat. J Med Food. 2009; 12: 21-8. doi: 10.1089/jmf.2008.0078.

170. Basu A, Du M, Leyva MJ, Sanchez K, Betts NM, Wu M, Aston CE, Lyons TJ. Blueberries decrease cardiovascular risk factors in obese men and women with metabolic syndrome. J Nutr. 2010; 140: 1582-7. doi: 10.3945/ jn.110.124701.

171. Kolehmainen M, Mykkänen O, Kirjavainen PV, Leppänen T, Moilanen E, Adriaens M, Laaksonen DE, Hallikainen M, Puupponen-Pimiä R, Pulkkinen L, Mykkänen H, Gylling H, Poutanen $\mathrm{K}$, et al. Bilberries reduce low-grade inflammation in individuals with features of metabolic syndrome. Molecular Nutrition \& Food Research. 2012; 56: 1501-10. doi: 10.1002/mnfr.201200195.

172. Basu A, Fu DX, Wilkinson M, Simmons B, Wu M, Betts NM, Du M, Lyons TJ. Strawberries decrease atherosclerotic markers in subjects with metabolic syndrome. Nutrition Research. 2010; 30: 462-9. doi: 10.1016/j. nutres.2010.06.016.

173. Mink PJ, Scrafford CG, Barraj LM, Harnack L, Hong C-P, Nettleton JA, Jacobs DR. Flavonoid intake and cardiovascular disease mortality: a prospective study in postmenopausal women. Am J Clin Nutr. 2007; 85: 895-909.

174. Stewart BW, Wild C, International Agency for Research on Cancer, World Health Organization. World cancer report 2014 [Internet]. Lyon; Geneva: International Agency for Research on Cancer; Distributed by WHO Press; 2014 [cited 2016 Dec 15]. Available from http://search.ebscohost. com/login.aspx ?direct $=$ true $\&$ scope $=$ site $\& d b=$ nlebk $\& d b=n l$ abk\&AN=979458

175. Vitale G, Salvioli S, Franceschi C. Oxidative stress and the ageing endocrine system. Nat Rev Endocrinol. 2013; 9: 228-40. doi: 10.1038/nrendo.2013.29.

176. Sozzani S, Bosisio D, Mantovani A, Ghezzi P. Linking stress, oxidation and the chemokine system. Eur J Immunol. 2005; 35: 3095-8. doi: 10.1002/eji.200535489.

177. Tieri P, Termanini A, Bellavista E, Salvioli S, Capri M, Franceschi C. Charting the NF- $\mathrm{B}$ pathway interactome map. PLoS ONE. 2012; 7: e32678. doi: 10.1371/journal. pone. 0032678 .

178. Aggarwal BB, Gehlot P. Inflammation and cancer: how friendly is the relationship for cancer patients? Current Opinion in Pharmacology. 2009; 9: 351-69. doi: 10.1016/j. coph.2009.06.020. 
179. Rotblat B, Grunewald TGP, Leprivier G, Melino G, Knight RA. Anti-oxidative stress response genes: bioinformatic analysis of their expression and relevance in multiple cancers. Oncotarget. 2013; 4: 2577-90. doi: 10.18632/ oncotarget. 1658 .

180. Park SY, Kim MJ, Park SA, Kim JS, Min KN, Kim DK, Lim W, Nam JS, Sheen YY. Combinatorial TGF- $\beta$ attenuation with paclitaxel inhibits the epithelial-to-mesenchymal transition and breast cancer stem-like cells. Oncotarget [Internet]. 2015;6:37526-43. doi: 10.18632/oncotarget.6063.

181. Ko H, Jeong M-H, Jeon H, Sung G-J, So Y, Kim I, Son J, Lee S, Yoon H-G, Choi K-C. Delphinidin sensitizes prostate cancer cells to TRAIL-induced apoptosis, by inducing DR5 and causing caspase-mediated HDAC3 cleavage. Oncotarget. 2015; 6: 9970-84. doi: 10.18632/ oncotarget.3667.

182. Itsumi M, Inoue S, Elia AJ, Murakami K, Sasaki M, Lind EF, Brenner D, Harris IS, Chio IIC, Afzal S, Cairns RA, Cescon DW, Elford AR, et al. Idh1 protects murine hepatocytes from endotoxin-induced oxidative stress by regulating the intracellular $\mathrm{NADP}(+) / \mathrm{NADPH}$ ratio. Cell Death Differ. 2015; 22: 1837-45. doi: 10.1038/cdd.2015.38.

183. Agostini M, Annicchiarico-Petruzzelli M, Melino G, Rufini A. Metabolic pathways regulated by TAp73 in response to oxidative stress. Oncotarget. 2016; 7: 29881-900. doi: 10.18632/oncotarget.8935.

184. Amelio I, Cutruzzolá F, Antonov A, Agostini M, Melino G. Serine and glycine metabolism in cancer. Trends Biochem Sci. 2014; 39: 191-8. doi: 10.1016/j.tibs.2014.02.004.

185. Chen P-M, Lin C-H, Li N-T, Wu Y-M, Lin M-T, Hung S-C, Yen M-L. c-Maf regulates pluripotency genes, proliferation/ self-renewal, and lineage commitment in ROS-mediated senescence of human mesenchymal stem cells. Oncotarget. 2015; 6: 35404-18. doi: 10.18632/oncotarget.6178.

186. Li H-Y, Zhang J, Sun L-L, Li B-H, Gao H-L, Xie T, Zhang N, Ye Z-M. Celastrol induces apoptosis and autophagy via the ROS/JNK signaling pathway in human osteosarcoma cells: an in vitro and in vivo study. Cell Death Dis. 2015; 6: e1604. doi: 10.1038/cddis.2014.543.

187. Calderon-Aparicio A, Strasberg-Rieber M, Rieber M. Disulfiram anti-cancer efficacy without copper overload is enhanced by extracellular $\mathrm{H} 2 \mathrm{O} 2$ generation: antagonism by tetrathiomolybdate. Oncotarget. 2015; 6: 29771-81. doi: 10.18632/oncotarget.4833.

188. Jacquemin G, Margiotta D, Kasahara A, Bassoy EY, Walch M, Thiery J, Lieberman J, Martinvalet D. Granzyme B-induced mitochondrial ROS are required for apoptosis. Cell Death Differ. 2015; 22: 862-74. doi: 10.1038/ cdd.2014.180.

189. Rotblat B, Southwell AL, Ehrnhoefer DE, Skotte NH, Metzler M, Franciosi S, Leprivier G, Somasekharan SP, Barokas A, Deng Y, Tang T, Mathers J, Cetinbas N, et al. HACE1 reduces oxidative stress and mutant Huntingtin toxicity by promoting the NRF2 response. Proc Natl
Acad Sci USA. 2014; 111: 3032-7. doi: 10.1073/ pnas. 1314421111.

190. Zhang C, Liu K, Yao K, Reddy K, Zhang Y, Fu Y, Yang G, Zykova TA, Shin SH, Li H, Ryu J, Jiang Y-N, Yin X, et al. HOI-02 induces apoptosis and G2-M arrest in esophageal cancer mediated by ROS. Cell Death Dis. 2015; 6: e1912. doi: 10.1038/cddis.2015.227.

191. Qin W, Li C, Zheng W, Guo Q, Zhang Y, Kang M, Zhang B, Yang B, Li B, Yang H, Wu Y. Inhibition of autophagy promotes metastasis and glycolysis by inducing ROS in gastric cancer cells. Oncotarget. 2015; 6: 39839-54. doi: 10.18632/oncotarget.5674.

192. Park M-T, Kim M-J, Suh Y, Kim R-K, Kim H, Lim E-J, Yoo K-C, Lee G-H, Kim Y-H, Hwang S-G, Yi J-M, Lee S-J. Novel signaling axis for ROS generation during K-Rasinduced cellular transformation. Cell Death Differ. 2014; 21: 1185-97. doi: 10.1038/cdd.2014.34.

193. Fitzgerald AL, Osman AA, Xie T-X, Patel A, Skinner $\mathrm{H}$, Sandulache V, Myers JN. Reactive oxygen species and $\mathrm{p} 21 \mathrm{Waf} 1 / \mathrm{Cip} 1$ are both essential for $\mathrm{p} 53$-mediated senescence of head and neck cancer cells. Cell Death Dis. 2015; 6: e1678. doi: 10.1038/cddis.2015.44.

194. Singer E, Judkins J, Salomonis N, Matlaf L, Soteropoulos P, McAllister S, Soroceanu L. Reactive oxygen speciesmediated therapeutic response and resistance in glioblastoma. Cell Death Dis. 2015; 6: e1601. doi: 10.1038/ cddis.2014.566.

195. Lee S-J, Jung YH, Oh SY, Jang KK, Lee HS, Choi SH, Han HJ. Vibrio vulnificus VvpE inhibits mucin 2 expression by hypermethylation via lipid raft-mediated ROS signaling in intestinal epithelial cells. Cell Death Dis. 2015; 6: e1787. doi: 10.1038/cddis.2015.152.

196. Hasanain M, Bhattacharjee A, Pandey P, Ashraf R, Singh N, Sharma S, Vishwakarma AL, Datta D, Mitra K, Sarkar J. $\alpha$-Solanine induces ROS-mediated autophagy through activation of endoplasmic reticulum stress and inhibition of Akt/mTOR pathway. Cell Death Dis. 2015; 6: e1860. doi: 10.1038/cddis.2015.219.

197. Zou P, Chen M, Ji J, Chen W, Chen X, Ying S, Zhang J, Zhang Z, Liu Z, Yang S, Liang G. Auranofin induces apoptosis by ROS-mediated ER stress and mitochondrial dysfunction and displayed synergistic lethality with piperlongumine in gastric cancer. Oncotarget. 2015; 6: 36505-21. doi: 10.18632/oncotarget.5364.

198. Palikaras K, Lionaki E, Tavernarakis N. Balancing mitochondrial biogenesis and mitophagy to maintain energy metabolism homeostasis. Cell Death Differ. 2015; 22: 1399-401. doi: 10.1038/cdd.2015.86.

199. Giordano L, Deceglie S, d'Adamo P, Valentino ML, La Morgia C, Fracasso F, Roberti M, Cappellari M, Petrosillo G, Ciaravolo S, Parente D, Giordano C, Maresca A, et al. Cigarette toxicity triggers Leber's hereditary optic neuropathy by affecting mtDNA copy number, oxidative phosphorylation and ROS detoxification pathways. Cell Death Dis. 2015; 6: e2021. doi: 10.1038/cddis.2015.364. 
200. Managò A, Leanza L, Carraretto L, Sassi N, Grancara S, Quintana-Cabrera R, Trimarco V, Toninello A, Scorrano L, Trentin L, Semenzato G, Gulbins E, Zoratti M, et al. Early effects of the antineoplastic agent salinomycin on mitochondrial function. Cell Death Dis. 2015; 6: e1930. doi: 10.1038/cddis.2015.263.

201. Guzzo G, Sciacovelli M, Bernardi P, Rasola A. Inhibition of succinate dehydrogenase by the mitochondrial chaperone TRAP1 has anti-oxidant and anti-apoptotic effects on tumor cells. Oncotarget. 2014; 5: 11897-908. doi: 10.18632/ oncotarget.2472.

202. Agostini M, Romeo F, Inoue S, Niklison-Chirou MV, Elia AJ, Dinsdale D, Morone N, Knight RA, Mak TW, Melino G. Metabolic reprogramming during neuronal differentiation. Cell Death Differ. 2016; 23: 1502-14. doi: 10.1038/cdd.2016.36.

203. Cho J, Seo J, Lim CH, Yang L, Shiratsuchi T, Lee M-H, Chowdhury RR, Kasahara H, Kim J-S, Oh SP, Lee YJ, Terada N. Mitochondrial ATP transporter Ant2 depletion impairs erythropoiesis and B lymphopoiesis. Cell Death Differ. 2015; 22: 1437-50. doi: 10.1038/cdd.2014.230.

204. Mei H, Sun S, Bai Y, Chen Y, Chai R, Li H. Reduced mtDNA copy number increases the sensitivity of tumor cells to chemotherapeutic drugs. Cell Death Dis. 2015; 6: e1710. doi: 10.1038/cddis.2015.78.

205. Liu J, Masurekar A, Johnson S, Chakraborty S, Griffiths J, Smith D, Alexander S, Dempsey C, Parker C, Harrison S, Li Y, Miller C, Di Y, et al. Stromal cell-mediated mitochondrial redox adaptation regulates drug resistance in childhood acute lymphoblastic leukemia. Oncotarget. 2015; 6: 43048-64. doi: 10.18632/oncotarget.5528.

206. Marini ES, Giampietri C, Petrungaro S, Conti S, Filippini A, Scorrano L, Ziparo E. The endogenous caspase-8 inhibitor c-FLIPL regulates ER morphology and crosstalk with mitochondria. Cell Death Differ. 2015; 22: 1131-43. doi: 10.1038/cdd.2014.197.

207. Kluckova K, Sticha M, Cerny J, Mracek T, Dong L, Drahota Z, Gottlieb E, Neuzil J, Rohlena J. Ubiquinone-binding site mutagenesis reveals the role of mitochondrial complex II in cell death initiation. Cell Death Dis. 2015; 6: e1749. doi: 10.1038/cddis.2015.110

208. Lee S-J, Jung YH, Oh SY, Song EJ, Choi SH, Han HJ. Vibrio vulnificus VvhA induces NF-кB-dependent mitochondrial cell death via lipid raft-mediated ROS production in intestinal epithelial cells. Cell Death Dis. 2015; 6: 1655. doi: 10.1038/cddis.2015.19.

209. Tian Y, Kuo C-F, Sir D, Wang L, Govindarajan S, Petrovic LM, Ou J-HJ. Autophagy inhibits oxidative stress and tumor suppressors to exert its dual effect on hepatocarcinogenesis. Cell Death Differ. 2015; 22: 1025-34. doi: 10.1038/ cdd.2014.201

210. Roberts DJ, Miyamoto S. Hexokinase II integrates energy metabolism and cellular protection: Akting on mitochondria and TORCing to autophagy. Cell Death Differ. 2015; 22: 248-57. doi: 10.1038/cdd.2014.173.
211. Filomeni G, De Zio D, Cecconi F. Oxidative stress and autophagy: the clash between damage and metabolic needs. Cell Death Differ. 2015; 22: 377-88. doi: 10.1038/ cdd.2014.150.

212. Gu Y, Barzegar M, Chen X, Wu Y, Shang C, Mahdavian E, Salvatore BA, Jiang S, Huang S. Fusarochromanoneinduced reactive oxygen species results in activation of JNK cascade and cell death by inhibiting protein phosphatases 2A and 5. Oncotarget. 2015; 6: 42322-33. doi: 10.18632/ oncotarget.5996.

213. Kostecka A, Sznarkowska A, Meller K, Acedo P, Shi Y, Mohammad Sakil HA, Kawiak A, Lion M, Królicka A, Wilhelm M, Inga A, Zawacka-Pankau J. JNK-NQO1 axis drives TAp73-mediated tumor suppression upon oxidative and proteasomal stress. Cell Death Dis. 2014; 5: e1484. doi: 10.1038/cddis.2014.408.

214. Maniam S, Coutts AS, Stratford MR, McGouran J, Kessler B, La Thangue NB. Cofactor Strap regulates oxidative phosphorylation and mitochondrial p53 activity through ATP synthase. Cell Death Differ. 2015; 22: 156-63. doi: 10.1038/cdd.2014.135.

215. Melino G, Memmi EM, Pelicci PG, Bernassola F. Maintaining epithelial stemness with p63. Sci Signal. 2015; 8: re9. doi: 10.1126/scisignal.aaa1033.

216. Candi E, Amelio I, Agostini M, Melino G. MicroRNAs and p63 in epithelial stemness. Cell Death Differ. 2015; 22: 12-21. doi: 10.1038/cdd.2014.113.

217. Viticchiè G, Agostini M, Lena AM, Mancini M, Zhou H, Zolla L, Dinsdale D, Saintigny G, Melino G, Candi E. p63 supports aerobic respiration through hexokinase II. Proc Natl Acad Sci USA. 2015; 112: 11577-82. doi: 10.1073/ pnas. 1508871112.

218. Memmi EM, Sanarico AG, Giacobbe A, Peschiaroli A, Frezza V, Cicalese A, Pisati F, Tosoni D, Zhou H, Tonon G, Antonov A, Melino G, Pelicci PG, et al. p63 Sustains selfrenewal of mammary cancer stem cells through regulation of Sonic Hedgehog signaling. Proc Natl Acad Sci USA. 2015; 112: 3499-504. doi: 10.1073/pnas.1500762112.

219. Rufini A, Niklison-Chirou MV, Inoue S, Tomasini R, Harris IS, Marino A, Federici M, Dinsdale D, Knight RA, Melino G, Mak TW. TAp73 depletion accelerates aging through metabolic dysregulation. Genes Dev. 2012; 26: 2009-14. doi: 10.1101/gad.197640.112.

220. Amelio I, Inoue S, Markert EK, Levine AJ, Knight RA, Mak TW, Melino G. TAp73 opposes tumor angiogenesis by promoting hypoxia-inducible factor $1 \alpha$ degradation. Proc Natl Acad Sci USA. 2015; 112: 226-31. doi: 10.1073/ pnas. 1410609111.

221. Amelio I, Melino G. The p53 family and the hypoxiainducible factors (HIFs): determinants of cancer progression. Trends Biochem Sci. 2015; 40: 425-34. doi: 10.1016/j.tibs.2015.04.007.

222. Ikeda K, Posillico JT, Boyle MB, Webb AC, Brown EM, Broadus AE. Microinjected Xenopus oocytes secrete 
mature, biologically active parathyroid hormone. Mol Endocrinol. 1989; 3: 1084-9. doi: 10.1210/mend-3-7-1084.

223. Gomez L, Thiebaut P-A, Paillard M, Ducreux S, Abrial M, Crola Da Silva C, Durand A, Alam MR, Van Coppenolle F, Sheu S-S, Ovize M. The SR/ER-mitochondria calcium crosstalk is regulated by GSK3 $\beta$ during reperfusion injury. Cell Death Differ. 2015; 22: 1890. doi: 10.1038/ cdd.2015.118.

224. Lamb R, Fiorillo M, Chadwick A, Ozsvari B, Reeves KJ, Smith DL, Clarke RB, Howell SJ, Cappello AR, MartinezOutschoorn UE, Peiris-Pagès M, Sotgia F, Lisanti MP. Doxycycline down-regulates DNA-PK and radiosensitizes tumor initiating cells: Implications for more effective radiation therapy. Oncotarget. 2015; 6: 14005-25. doi: 10.18632/oncotarget.4159.

225. Hugle M, Belz K, Fulda S. Identification of synthetic lethality of PLK1 inhibition and microtubule-destabilizing drugs. Cell Death Differ. 2015; 22: 1946-56. doi: 10.1038/ cdd.2015.59.

226. Javadov S, Jang S, Rodriguez-Reyes N, Rodriguez-Zayas AE, Soto Hernandez J, Krainz T, Wipf P, Frontera W. Mitochondria-targeted antioxidant preserves contractile properties and mitochondrial function of skeletal muscle in aged rats. Oncotarget. 2015; 6: 39469-81. doi: 10.18632/ oncotarget.5783.

227. Dho SH, Kim JY, Kwon E-S, Lim JC, Park SS, Kwon K-S. NOX5-L can stimulate proliferation and apoptosis depending on its levels and cellular context, determining cancer cell susceptibility to cisplatin. Oncotarget. 2015; 6: 39235-46. doi: 10.18632/oncotarget.5743.

228. Liu L, Zou P, Zheng L, Linarelli LE, Amarell S, Passaro A, Liu D, Cheng Z. Tamoxifen reduces fat mass by boosting reactive oxygen species. Cell Death Dis. 2015; 6: e1586. doi: 10.1038/cddis.2014.553.

229. Martinez BA, Kim H, Ray A, Caldwell GA, Caldwell KA. A bacterial metabolite induces glutathione-tractable proteostatic damage, proteasomal disturbances, and PINK1dependent autophagy in C. elegans. Cell Death Dis. 2015; 6: e1908. doi: 10.1038/cddis.2015.270.

230. Granato M, Gilardini Montani MS, Filardi M, Faggioni A, Cirone M. Capsaicin triggers immunogenic PEL cell death, stimulates DCs and reverts PEL-induced immune suppression. Oncotarget. 2015; 6: 29543-54. doi: 10.18632/ oncotarget.4911.

231. Beker MC, Caglayan AB, Kelestemur T, Caglayan B, Yalcin E, Yulug B, Kilic U, Hermann DM, Kilic E. Effects of normobaric oxygen and melatonin on reperfusion injury: role of cerebral microcirculation. Oncotarget. 2015; 6: 30604-14. doi: 10.18632/oncotarget.5773.

232. Zhao H, Ning S, Scicinski J, Oronsky B, Knox SJ, Peehl DM. Epigenetic effects of RRx-001: a possible unifying mechanism of anticancer activity. Oncotarget. 2015; 6: 43172-81. doi: 10.18632/oncotarget.6526.
233. Yadav N, Kumar S, Marlowe T, Chaudhary AK, Kumar R, Wang J, O’Malley J, Boland PM, Jayanthi S, Kumar TKS, Yadava N, Chandra D. Oxidative phosphorylationdependent regulation of cancer cell apoptosis in response to anticancer agents. Cell Death Dis. 2015; 6: e1969. doi: 10.1038/cddis.2015.305.

234. Solaini G, Sgarbi G, Baracca A. Oxidative phosphorylation in cancer cells. Biochimica et Biophysica Acta (BBA)Bioenergetics. 2011; 1807: 534-42. doi: 10.1016/j. bbabio.2010.09.003.

235. Li K, Gao B, Li J, Chen H, Li Y, Wei Y, Gong D, Gao J, Zhang J, Tan W, Wen T, Zhang L, Huang L, et al. ZNF32 protects against oxidative stress-induced apoptosis by modulating C1QBP transcription. Oncotarget. 2015; 6: 38107-26. doi: 10.18632/oncotarget.5646.

236. Pérez-López FR, Chedraui P, Haya J, Cuadros JL. Effects of the Mediterranean diet on longevity and age-related morbid conditions. Maturitas. 2009; 64: 67-79. doi: 10.1016/j. maturitas.2009.07.013.

237. Noto D, Cefalù AB, Barbagallo CM, Ganci A, Cavera G, Fayer F, Palesano O, Spina R, Valenti V, Altieri GI, Caldarella R, Giammanco A, Termini R, et al. Baseline metabolic disturbances and the twenty-five years risk of incident cancer in a Mediterranean population. Nutr Metab Cardiovasc Dis. 2016; 26: 1020-5. doi: 10.1016/j. numecd.2016.07.003.

238. Arnold M, Leitzmann M, Freisling H, Bray F, Romieu I, Renehan A, Soerjomataram I. Obesity and cancer: An update of the global impact. Cancer Epidemiol. 2016; 41: 8-15. doi: 10.1016/j.canep.2016.01.003.

239. Vainio H, International Agency for Research on Cancer, International Agency for Research on Cancer, editors. Weight control and physical activity. Lyon: IARC Press; 2002. 315 p.

240. Fader AN, Beavis A, Smith A. Lifestyle changes and the risk of developing endometrial and ovarian cancers: opportunities for prevention and management. International Journal of Women's Health. 2016; : 151. doi: 10.2147/ IJWH.S88367.

241. Ma Y, Yang Y, Wang F, Zhang P, Shi C, Zou Y, Qin H. Obesity and risk of colorectal cancer: a systematic review of prospective studies. PLoS ONE. 2013; 8: e53916. doi: 10.1371/journal.pone.0053916.

242. Chen Y, Liu L, Wang X, Wang J, Yan Z, Cheng J, Gong G, Li G. Body mass index and risk of gastric cancer: a metaanalysis of a population with more than ten million from 24 prospective studies. Cancer Epidemiol Biomarkers Prev. 2013; 22: 1395-408. doi: 10.1158/1055-9965.EPI-13-0042.

243. Rai A, Mohapatra SC, Shukla HS. A review of association of dietary factors in gallbladder cancer. Indian J Cancer. 2004; 41: 147-51.

244. Wang F, Xu Y. Body mass index and risk of renal cell cancer: a dose-response meta-analysis of published cohort 
studies. Int J Cancer. 2014; 135: 1673-86. doi: 10.1002/ ijc. 28813 .

245. Grosso G, Buscemi S, Galvano F, Mistretta A, Marventano S, La Vela V, Drago F, Gangi S, Basile F, Biondi A. Mediterranean diet and cancer: epidemiological evidence and mechanism of selected aspects. BMC Surg. 2013; 13 Suppl 2: S14. doi: 10.1186/1471-2482-13-S2-S14.

246. Sofi F, Abbate R, Gensini GF, Casini A. Accruing evidence on benefits of adherence to the Mediterranean diet on health: an updated systematic review and meta-analysis. Am J Clin Nutr. 2010; 92: 1189-96. doi: 10.3945/ajcn.2010.29673.

247. Couto E, Boffetta P, Lagiou P, Ferrari P, Buckland G, Overvad K, Dahm CC, Tjønneland A, Olsen A, ClavelChapelon F, Boutron-Ruault M-C, Cottet V, Trichopoulos $\mathrm{D}$, et al. Mediterranean dietary pattern and cancer risk in the EPIC cohort. British Journal of Cancer. 2011; 104: 1493-9. doi: 10.1038/bjc.2011.106.

248. Carruba G, Granata OM, Pala V, Campisi I, Agostara B, Cusimano R, Ravazzolo B, Traina A. A traditional Mediterranean diet decreases endogenous estrogens in healthy postmenopausal women. Nutr Cancer. 2006; 56: 253-9. doi: 10.1207/s15327914nc5602_18.

249. Castagnetta LAM, Granata OM, Traina A, Ravazzolo B, Amoroso M, Miele M, Bellavia V, Agostara B, Carruba G. Tissue content of hydroxyestrogens in relation to survival of breast cancer patients. Clin Cancer Res. 2002; 8: 3146-55.

250. Steck SE, Guinter M, Zheng J, Thomson CA. Index-Based Dietary Patterns and Colorectal Cancer Risk: A Systematic Review. Advances in Nutrition: An International Review Journal. 2015; 6: 763-73. doi: 10.3945/an.115.009746.

251. Colotta F, Allavena P, Sica A, Garlanda C, Mantovani A. Cancer-related inflammation, the seventh hallmark of cancer: links to genetic instability. Carcinogenesis. 2009; 30: 1073-81. doi: 10.1093/carcin/bgp127.

252. Barera A, Buscemi S, Monastero R, Caruso C, Caldarella $\mathrm{R}$, Ciaccio M, Vasto S. $\beta$-glucans: ex vivo inflammatory and oxidative stress results after pasta intake. Immun Ageing. 2016; 13: 14. doi: 10.1186/s12979-016-0068-x.

253. Decarli A, La Vecchia C, Cislaghi C, Mezzanotte G, Marubini E. Descriptive epidemiology of gastric cancer in Italy. Cancer. 1986; 58: 2560-9.

254. La Vecchia C, D’Avanzo B, Negri E, Decarli A, Benichou J. Attributable risks for stomach cancer in northern Italy. Int J Cancer. 1995; 60: 748-52.

255. Praud D, Bertuccio P, Bosetti C, Turati F, Ferraroni M, La Vecchia C. Adherence to the Mediterranean diet and gastric cancer risk in Italy. Int J Cancer. 2014; 134: 2935-41. doi: 10.1002/ijc.28620.

256. Giraldi L, Panic N, Cadoni G, Boccia S, Leoncini E. Association between Mediterranean diet and head and neck cancer: results of a large case-control study in Italy. Eur J Cancer Prev. 2016; . doi: 10.1097/CEJ.0000000000000277.

257. Bosetti C, Gallus S, Trichopoulou A, Talamini R, Franceschi $\mathrm{S}$, Negri E, La Vecchia C. Influence of the Mediterranean diet on the risk of cancers of the upper aerodigestive tract. Cancer Epidemiol Biomarkers Prev. 2003; 12: 1091-4.

258. Jacobs DR, Marquart L, Slavin J, Kushi LH. Wholegrain intake and cancer: an expanded review and meta-analysis. Nutr Cancer. 1998; 30: 85-96. doi: 10.1080/01635589809514647.

259. Norat T, Aune D, Chan D, Romaguera D. Fruits and vegetables: updating the epidemiologic evidence for the WCRF/AICR lifestyle recommendations for cancer prevention. Cancer Treat Res. 2014; 159: 35-50. doi: 10.1007/978-3-642-38007-5_3.

260. Chatenoud L, La Vecchia C, Franceschi S, Tavani A, Jacobs DR, Parpinel MT, Soler M, Negri E. Refined-cereal intake and risk of selected cancers in italy. Am J Clin Nutr. 1999; 70: 1107-10.

261. Mudryj AN, Yu N, Aukema HM. Nutritional and health benefits of pulses. Appl Physiol Nutr Metab. 2014; 39: 1197-204. doi: 10.1139/apnm-2013-0557.

262. Falasca M, Casari I, Maffucci T. Cancer chemoprevention with nuts. J Natl Cancer Inst. 2014; 106. doi: 10.1093/jnci/ dju238.

263. Yeh C-C, You S-L, Chen C-J, Sung F-C. Peanut consumption and reduced risk of colorectal cancer in women: a prospective study in Taiwan. World J Gastroenterol. 2006; 12: 222-7.

264. American Institute for Cancer Research, World Cancer Research Fund, editors. Food, nutrition, physical activity and the prevention of cancer: a global perspective: a project of World Cancer Research Fund International. Washington, D.C: American Institute for Cancer Research; 2007. 517 p.

265. Shufelt C, Merz CNB, Yang Y, Kirschner J, Polk D, Stanczyk F, Paul-Labrador M, Braunstein GD. Red Versus White Wine as a Nutritional Aromatase Inhibitor in Premenopausal Women: A Pilot Study. Journal of Women's Health. 2012; 21: 281-4. doi: 10.1089/jwh.2011.3001.

266. Arranz S, Chiva-Blanch G, Valderas-Martínez P, MedinaRemón A, Lamuela-Raventós RM, Estruch R. Wine, beer, alcohol and polyphenols on cardiovascular disease and cancer. Nutrients. 2012; 4: 759-81. doi: 10.3390/nu4070759.

267. D’Alessandro A, De Pergola G, Silvestris F. Mediterranean Diet and cancer risk: an open issue. International Journal of Food Sciences and Nutrition. 2016; 67: 593-605. doi: 10.1080/09637486.2016.1191444.

268. Schwingshackl L, Hoffmann G. Does a Mediterranean-Type Diet Reduce Cancer Risk? Curr Nutr Rep. 2016; 5: 9-17. doi: 10.1007/s13668-015-0141-7.

269. Ostan R, Lanzarini C, Pini E, Scurti M, Vianello D, Bertarelli C, Fabbri C, Izzi M, Palmas G, Biondi F, Martucci M, Bellavista E, Salvioli S, et al. Inflammaging and Cancer: A Challenge for the Mediterranean Diet. Nutrients. 2015; 7: 2589-621. doi: 10.3390/nu7042589.

270. Paul L. Diet, nutrition and telomere length. The Journal of Nutritional Biochemistry. 2011; 22: 895-901. doi: 10.1016/j.jnutbio.2010.12.001. 
271. Rafie N, Golpour Hamedani S, Barak F, Safavi SM, Miraghajani M. Dietary patterns, food groups and telomere length: a systematic review of current studies. Eur J Clin Nutr. 2016; . doi: 10.1038/ejen.2016.149.

272. Epel ES, Lin J, Wilhelm FH, Wolkowitz OM, Cawthon R, Adler NE, Dolbier C, Mendes WB, Blackburn EH. Cell aging in relation to stress arousal and cardiovascular disease risk factors. Psychoneuroendocrinology. 2006; 31: 277-87. doi: 10.1016/j.psyneuen.2005.08.011.

273. Hu FB. Plant-based foods and prevention of cardiovascular disease: an overview. Am J Clin Nutr. 2003; 78: 544S-551S.

274. Anderson AL, Harris TB, Tylavsky FA, Perry SE, Houston DK, Hue TF, Strotmeyer ES, Sahyoun NR, Health ABC Study. Dietary patterns and survival of older adults. J Am Diet Assoc. 2011; 111: 84-91. doi: 10.1016/j. jada.2010.10.012.

275. Boccardi V, Esposito A, Rizzo MR, Marfella R, Barbieri M, Paolisso G. Mediterranean Diet, Telomere Maintenance and Health Status among Elderly. Vinciguerra M, editor. PLoS ONE. 2013; 8: e62781. doi: 10.1371/journal.pone.0062781.

276. Tiainen A-MK, Männistö S, Blomstedt PA, Moltchanova E, Perälä M-M, Kaartinen NE, Kajantie E, Kananen L, Hovatta I, Eriksson JG. Leukocyte telomere length and its relation to food and nutrient intake in an elderly population. Eur J Clin Nutr. 2012; 66: 1290-4. doi: 10.1038/ejen.2012.143.

277. Knoops KTB, Groot de LC, Fidanza F, Alberti-Fidanza A, Kromhout D, van Staveren WA. Comparison of three different dietary scores in relation to 10 -year mortality in elderly European subjects: the HALE project. European Journal of Clinical Nutrition. 2006; 60: 746-55. doi: 10.1038/sj.ejcn.1602378.

278. Crous-Bou M, Fung TT, Prescott J, Julin B, Du M, Sun Q, Rexrode KM, Hu FB, De Vivo I. Mediterranean diet and telomere length in Nurses' Health Study: population based cohort study. BMJ. 2014; 349: g6674.

279. Zbeida M, Goldsmith R, Shimony T, Vardi H, Naggan L, Shahar DR. Mediterranean diet and functional indicators among older adults in non-Mediterranean and Mediterranean countries. The journal of nutrition, health \& aging. 2014; 18: 411-8. doi: 10.1007/s12603-014-0003-9.

280. Valls-Pedret C, Sala-Vila A, Serra-Mir M, Corella D, de la Torre R, Martínez-González MÁ, Martínez-Lapiscina EH, Fitó M, Pérez-Heras A, Salas-Salvadó J, Estruch R, Ros E. Mediterranean Diet and Age-Related Cognitive Decline: A Randomized Clinical Trial. JAMA Internal Medicine. 2015; 175: 1094. doi: 10.1001/jamainternmed.2015.1668.

281. Trichopoulou A, Costacou T, Bamia C, Trichopoulos D. Adherence to a Mediterranean diet and survival in a Greek population. N Engl J Med. 2003; 348: 2599-608. doi: 10.1056/NEJMoa025039.

282. Marin C, Delgado-Lista J, Ramirez R, Carracedo J, Caballero J, Perez-Martinez P, Gutierrez-Mariscal FM, Garcia-Rios A, Delgado-Casado N, Cruz-Teno C, YuberoSerrano EM, Tinahones F, Malagon $\mathrm{M}$ del $\mathrm{M}$, et al.
Mediterranean diet reduces senescence-associated stress in endothelial cells. AGE. 2012; 34: 1309-16. doi: 10.1007/ s11357-011-9305-6.

283. Iantorno M, Campia U, Di Daniele N, Nistico S, Forleo GB, Cardillo C, Tesauro M. Obesity, inflammation and endothelial dysfunction. J Biol Regul Homeost Agents. 2014; 28: 169-76.

284. Fernández del Río L, Gutiérrez-Casado E, Varela-López A, Villalba J. Olive Oil and the Hallmarks of Aging. Molecules. 2016; 21: 163. doi: 10.3390/molecules21020163.

285. Santiago-Mora R, Casado-Díaz A, De Castro MD, QuesadaGómez JM. Oleuropein enhances osteoblastogenesis and inhibits adipogenesis: the effect on differentiation in stem cells derived from bone marrow. Osteoporos Int. 2011; 22: 675-84. doi: 10.1007/s00198-010-1270-x.

286. Beauchamp GK, Keast RSJ, Morel D, Lin J, Pika J, Han Q, Lee C-H, Smith AB, Breslin PAS. Phytochemistry: ibuprofen-like activity in extra-virgin olive oil. Nature. 2005; 437: 45-6. doi: 10.1038/437045a.

287. Agudo A, Cabrera L, Amiano P, Ardanaz E, Barricarte A, Berenguer T, Chirlaque MD, Dorronsoro M, Jakszyn P, Larrañaga N, Martínez C, Navarro C, Quirós JR, et al. Fruit and vegetable intakes, dietary antioxidant nutrients, and total mortality in Spanish adults: findings from the Spanish cohort of the European Prospective Investigation into Cancer and Nutrition (EPIC-Spain). Am J Clin Nutr. 2007; 85: 1634-42.

288. Longo VD, Antebi A, Bartke A, Barzilai N, Brown-Borg HM, Caruso C, Curiel TJ, de Cabo R, Franceschi C, Gems D, Ingram DK, Johnson TE, Kennedy BK, et al. Interventions to Slow Aging in Humans: Are We Ready? Aging Cell. 2015; 14: 497-510. doi: 10.1111/acel.12338.

289. de Lorgeril M, Salen P, Martin JL, Monjaud I, Delaye J, Mamelle N. Mediterranean diet, traditional risk factors, and the rate of cardiovascular complications after myocardial infarction: final report of the Lyon Diet Heart Study. Circulation. 1999; 99: 779-85.

290. Expert Panel on Detection, Evaluation, and Treatment of High Blood Cholesterol in Adults. Executive Summary of The Third Report of The National Cholesterol Education Program (NCEP) Expert Panel on Detection, Evaluation, And Treatment of High Blood Cholesterol In Adults (Adult Treatment Panel III). JAMA. 2001; 285: 2486-97.

291. Alberti KGMM, Zimmet P, Shaw J, IDF Epidemiology Task Force Consensus Group. The metabolic syndrome--a new worldwide definition. Lancet. 2005; 366: 1059-62. doi: 10.1016/S0140-6736(05)67402-8.

292. Hamer M, McNaughton SA, Bates CJ, Mishra GD. Dietary patterns, assessed from a weighed food record, and survival among elderly participants from the United Kingdom. Eur J Clin Nutr. 2010; 64: 853-61. doi: 10.1038/ejen.2010.93.

293. L.J. Dominguez. Healthy aging and Mediterranean diet. 2014; 62: 157-60. 